\title{
State of Art of Alkaline Earth Metal Oxides Catalysts Used in the Transesterification of Oils for Biodiesel Production
}

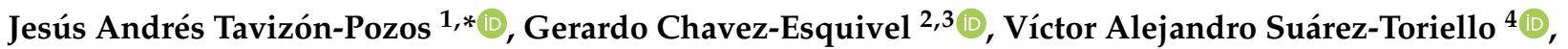 \\ Carlos Eduardo Santolalla-Vargas ${ }^{5}{ }^{\circledR}$, Oscar Abel Luévano-Rivas ${ }^{4,6}$, Omar Uriel Valdés-Martínez ${ }^{6}$, \\ Alfonso Talavera-López ${ }^{7}$ and Jose Antonio Rodriguez ${ }^{8}$ (D)
}

check for updates

Citation: Tavizón-Pozos, J.A.; Chavez-Esquivel, G.; Suárez-Toriello, V.A.; Santolalla-Vargas, C.E.; Luévano-Rivas, O.A.; Valdés-Martínez, O.U.;

Talavera-López, A.; Rodriguez, J.A. State of Art of Alkaline Earth Metal Oxides Catalysts Used in the Transesterification of Oils for Biodiesel Production. Energies 2021, 14, 1031. https://doi.org/10.3390/ en14041031

Academic Editor: Andrzej L. Wasiak

Received: 21 January 2021

Accepted: 12 February 2021

Published: 16 February 2021

Publisher's Note: MDPI stays neutral with regard to jurisdictional claims in published maps and institutional affiliations.

Copyright: (c) 2021 by the authors. Licensee MDPI, Basel, Switzerland. This article is an open access article distributed under the terms and conditions of the Creative Commons Attribution (CC BY) license (https:/ / creativecommons.org/licenses/by/ $4.0 /)$.
1 Cátedras CONACYT-Área Académica de Química, Universidad Autónoma del Estado de Hidalgo, Carr. Pachuca-Tulancingo km 4.5, Pachuca C.P. 42184, Mexico

2 Departamento de Ciencias Básicas, Universidad Autónoma Metropolitana-Azcapotzalco, Av. San Pablo 180, Azcapotzalco, Ciudad de México C.P. 02200, Mexico; gce@azc.uam.mx

3 Instituto de Física, Universidad Nacional Autónoma de México, Circuito de la Investigación Científica, Ciudad Universitaria, Ciudad de México C.P. 04510, Mexico

4 C. CONACYT-CIATEC, Centro de Innovación Aplicada en Tecnologías Competitivas, Omega 201, Industrial Delta, León 37545, Mexico; vsuarezt@conacyt.mx (V.A.S.-T.); oalr@xanum.uam.mx (O.A.L.-R.)

5 Departamento de Biociencias e Ingeniería, Centro Interdisciplinario de Investigaciones y Estudios sobre Medio Ambiente y Desarrollo, Instituto Politécnico Nacional, Ciudad de México C.P. 07340, Mexico; csantolallav@ipn.mx

6 Departamento de Ingeniería de Procesos e Hidráulica, Universidad Autónoma Metropolitana-Iztapalapa, Av. San Rafael Atlixco No. 86, Col. Leyes de Reforma $1^{a}$ Secc., Iztapalapa, Ciudad de México C.P. 09310, Mexico; omar.vama@xanum.uam.mx

7 Unidad de Ciencias Químicas, Universidad Autónoma de Zacatecas, Carr. A Guadalajara km 6, Ejido la Escondida, Zacatecas C.P. 98160, Mexico; talavera@uaz.edu.mx

8 Área Académica de Química, Universidad Autónoma del Estado de Hidalgo, Carr. Pachuca-Tulancingo km 4.5, Pachuca C.P. 42184, Mexico; josear@uaeh.edu.mx

* Correspondence: jesus.tavizon@conacyt.mx

Abstract: Biodiesel produced through catalytic transesterification of triglycerides from edible and non-edible oils and alcohol is considered an alternative to traditional petro-diesel. The interest in the use of alkaline earth metal oxides as heterogeneous basic catalysts has increased due to their availability, non-toxicity, the capacity to be reused, low cost, and high concentration of surface basic sites that provide the activity. This work is a compilation of the strategies to understand the effect of the source, synthesis, and thermal treatment of $\mathrm{MgO}, \mathrm{CaO}, \mathrm{SrO}$, and $\mathrm{BaO}$ on the improvement of the surface basic sites density and strength, the morphology of the solid structure, stability during reaction and reusability. These parameters are commonly modified or enhanced by mixing these oxides or with alkaline metals. Also, the improvement of the acid-base properties and to avoid the lixiviation of catalysts can be achieved by supporting the alkaline earth metal oxides on another oxide. Additionally, the effect of the most relevant operation conditions in oil transesterification reactions such as methanol to oil ratio, temperature, agitation method, pressure, and catalysts concentration are reviewed. This review attempts to elucidate the optimum parameters of reaction and their application in different oils.

Keywords: biodiesel; alkaline-earth metals; heterogeneous catalysts; transesterification; basicity; operation conditions; recycle; vegetable oils; wasted cooking oils

\section{Introduction}

Nowadays, oil is the primary energy source worldwide since it is used mainly as fuel for transportation and electric power plants. The world population's growth has caused an increase in demand for petroleum-derived products, a non-renewable source. The mathematical models have projected that oil could be scarce between 2048 and 2058 [1]. On the one hand, economic dependence on oil has produced war, political, and economic 
conflicts in oil-producing countries. Particularly, in 2020, the oil prices have been highly unstable due to the pandemic caused by the novel virus SARS-CoV-2 and the excessive oil production, affecting the economies of the producer countries [2]. Additionally, the burning of fossil fuels is responsible for the emission of greenhouse gases which are the cause of the climate crisis. In 2018, approximately $23-29 \%$ of the total $\mathrm{CO}_{2}$ generated, came from fuels used in transportation and has reached more than $400 \mathrm{ppm}$ in the atmosphere, which has increased the average terrestrial temperature [3-7]. In this sense, humans must mitigate and delay negative effects through the education, green chemistry, and development of sustainable and renewable technologies and actions. Following the objectives of the Paris Agreements in 2016, an annual increase in the development and use of renewable energy sources has been promoted thanks to the support and subsidies in biofuel prices by governments [8-10]. Therefore, the use of biomass as an alternative, renewable and clean source has drawn the attention of scientists to reduce environmental impact. Particularly the development of biofuels seems to be a viable, economical, clean, and potentially applicable option to rural societies [11,12].

\subsection{Biofuels}

Biofuels are generated from different sources of biomass, such as crops, seeds, agroindustry wastes, and algae, which have the characteristic of being renewable, not toxic, accessible, cheap, with lower sulfur and nitrogen content, and a faster reintegration of $\mathrm{CO}_{2}$ emitted to the carbon cycle [11,13-15]. However, the use of biofuels could not cover the entire demand for fuels on the planet because their production depends on the quality, availability, and production of biomass. In this way, biofuels can potentially be used in small towns or mixed with fossil fuels not only to reduce the consumption and import of the latter but also for rural economic activation purposes [16,17]. The transformation of biomass in biorefineries can lead to value-added products that are used as additives or raw material for other processes and products [18].

Biofuels are divided into four generations (1G, 2G, 3G, and 4G) depending on the source from which they were synthesized, and all seek to reduce the oxygen content of the molecules that make up the biomass to increase energy density and increase the molecular weight of hydrocarbons [19]. 1G biofuels are obtained from edible or inedible crops, 2G biofuels from biomass waste such as sawdust or wood. 3G and 4G biofuels are produced from algae and microorganisms that can be genetically modified to improve their characteristics $[20,21]$. The biodiesel obtained through the transesterification of vegetable oils $(1 \mathrm{G})$ is the most produced biofuel worldwide. Consequently, several studies have focused on developing the optimization of this process and its catalysts [22-24]. The latter is an important factor in the improvement of biodiesel production systems since they determine the quality and quantity of biodiesel, as well as the ecological impact that the plant can have. In this sense, the main objective of this work is to review and analyze the synergy of operating conditions and the development of catalysts that optimize the production of biofuels through transesterification reactions of vegetable oils.

$1 \mathrm{G}$ biofuels, also called conventional biofuels, are produced from agronomic crops from which sugars and starches are extracted to generate alcohols (bioethanol) and vegetable oils that are transformed into biodiesel. Biofuels are safe, have good quality due to the high cetane or octane numbers, and can be mixed with fossil fuel loads to decrease the carbon footprint [25]. These biofuels are the most developed and used industrially due to their reduced production costs and relative simplicity in their processes and have a carbon footprint near to neutral $[8,17,26]$. Biodiesel is generated from edible and non-edible vegetable oils such as canola, corn, soybean, castor, jatropha, olive, coconut, peanut, palm, cotton, cane, wheat, and fruit oils, and even from oil generated from algae and microalgae [27]. Also, it can be generated from animal fat and edible waste oils from restaurants or businesses. However, it is well known that obtaining biodiesel from edible oils creates competition with the food industry, so that food prices and their availability could be compromised by fuel demand. Likewise, they present environmental impacts that lead 
to deforestation for cultivation and massive use of fertilizers [28,29]. Hence, the use of wasted oils and non-edible oils would help to reduce competition with food production and increase sustainable production in developing countries [30-32].

Biodiesel is mainly composed of a combination of fatty acid methyl esters (FAME) or fatty acid ethyl esters (FAEE) derived from triglycerides and fatty acids that make up vegetable oils and animal fats that can be incorporated into petroleum diesel fillers [33]. This fuel has the advantage of being biodegradable, renewable, presenting low toxicity, high energy value (39-41 MJ $/ \mathrm{kg}$ ), and having more lubrication than conventional petroleum diesel. However, the molecular structures of fatty acid chains, such as length or unsaturation, affect the quality of biodiesel. At low temperatures, it can become a gel that could cover the filters, or the unsaturation of the chains can oxidize and degrade the fuel $[34,35]$. Therefore, to improve the quality of biodiesel it is necessary to conduct studies on the process conditions, kinetics, and functionalities of the catalysts.

\subsection{Transesterification of Triglycerides}

The transesterification of triglycerides from vegetable oils with alcohols in the presence of a catalyst to generate FAME and glycerol as a by-product is shown in Figure 1. Methanol and ethanol are the most used alcohols for these reactions since they can be formed from fermentation, so they are accessible and present a low cost; besides, they easily dissolve homogeneous catalysts [36]. Because the reaction is reversible, an excess of alcohol is necessary to shift the equilibria towards the products [37].

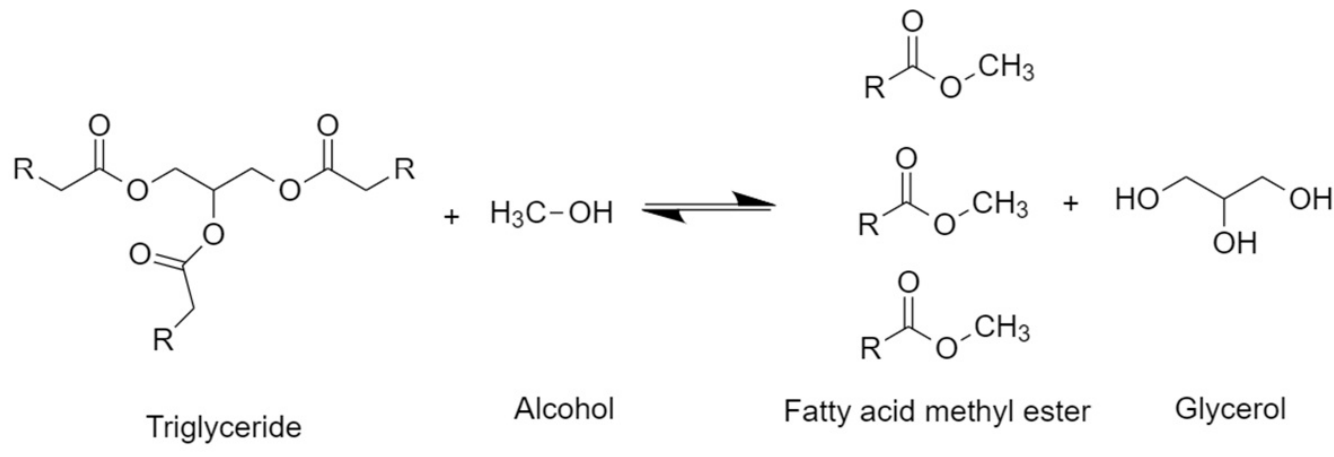

Figure 1. General scheme of the transesterification reaction of triglycerides with methanol.

First, a triglyceride reacts with alcohol to give a molecule of fatty acid methyl ester and one of diglyceride. The latter reacts with another molecule of alcohol to generate another molecule of fatty acid methyl ester and a monoglyceride, which repeats the same procedure. Therefore, stoichiometrically requires a 3:1 molar ratio of alcohol to triglyceride to form three molecules of FAME and one of glycerol [38,39]. Commonly, transesterification reactions at the industrial level are carried out by a homogeneous catalyst with a strong basic character, such as $\mathrm{NaOH}$ and $\mathrm{KOH}$. However, strong acids such as $\mathrm{H}_{2} \mathrm{SO}_{4}$ and $\mathrm{HCl}$, enzymes like lipases, and heterogeneous catalysts can be used as well [40-42]. After the reaction, two phases are generated: the biodiesel (FAME) phase at the top and the glycerol phase at the bottom. This latter consists of a mixture of compounds present from the vegetable oil such as water, organic compounds which gave color and flavor to the oil, inorganic salts, alcohol, glycerides, and catalyst. Hence, after simple decantation, this byproduct can be separated and then purified to be used as raw material for other processes. Free fatty acids (FFA) present in the oil can be transformed into esters by an esterification reaction in the presence of an acid catalyst such as $\mathrm{H}_{2} \mathrm{SO}_{4}$ (Figure 2). 


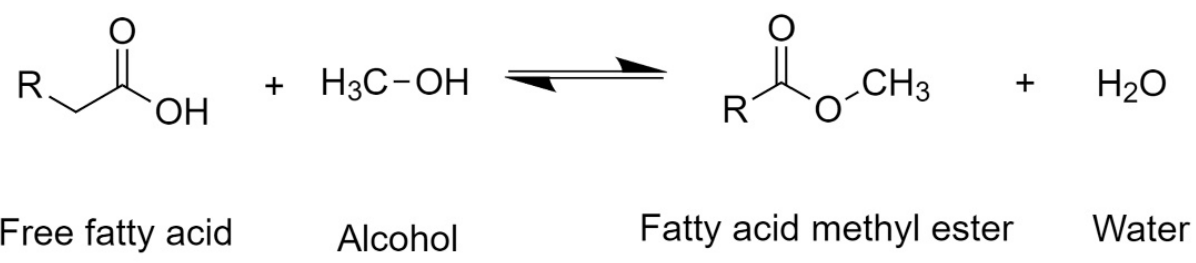

Figure 2. General scheme of the esterification reaction of free fatty acids with methanol.

In this reaction, the oxygen of the carbonyl group is first protonated by the acid catalyst generating a cationic complex. The oxygen in the alcohol then nucleophilically attacks the carbon in the carbonyl group of the complex. Finally, hydrogen bonds to the hydroxyl group of the acid, forming water and a FAME molecule [43,44]. In both processes, it has been seen that the reaction performance depends mainly on the molar ratio between alcohol and triglyceride (or FFA), temperature, and the amount of catalyst used [37,45].

\subsection{Catalysts}

The use of homogenous catalysts has advantages such as high activity and availability, low cost, moderate operating conditions (atmospheric pressure and $50-70{ }^{\circ} \mathrm{C}$ ), and production of high-quality biodiesel. On the one hand, glycerol forms a thick organic phase that precipitates, so it is relatively easy to separate from biodiesel by centrifugation or decantation. On the other hand, the methanol that is diluted with biodiesel can be recovered by distillation and reused. However, since the homogeneous catalyst is in the same phase as the oil, FAME, and glycerol; it must be separated by a purification process [46]. To achieve this, large amounts of water are required, which results in contamination, increase in the cost of the process, and there is a risk that it will result in the saponification of FFA consuming the catalyst and making the separation of biodiesel difficult $[47,48]$. Thus, it has been determined that vegetable oil must have a maximum of 1 wt.\% FFA and less than 0.06 wt.\% water to maximize FAME formation [49]. In parallel, strong acids can also be used as homogeneous catalysts, preferably in loads of used oil or animal fats, since they have a high FFA content [50]. Like the basic catalysts, their operating conditions are moderate and require high alcohol/oil molar ratios to obtain acceptable yields [51]. Nevertheless, unlike basic catalysts, acid catalysts do not run the risk of unwanted saponification reactions and can perform transesterification and esterification simultaneously [52-54]. The acid catalysts can directly produce biodiesel from low-grade, highly acidic, and water-containing oils. Despite this, their activity is relatively low in transesterification compared to basic catalysts. Moreover, they are highly corrosive, toxic and the separation processes involved are more complex and require greater amounts of water than basic catalysts. Water addition provokes a rapid separation of the two phases by the formation of hydrogen bonds between solvent and water that are energetically more favorable than the van der Waals interactions between alcohol and biodiesel. Hence it interrupts the emulsifying action of alcohol with an immediate separation of glycerol from biodiesel [53]. Optimization studies in biofuel production have used a different design of experiment methods [55]. In current literature, it is possible to find several studies that have compared and used different types of oils and methods to find the relationships between operational conditions and optimize their values. For example, Veljkovic et al. [56] conducted a study in which the methods of Box-Behnken, face-centered composite, and full factorial in the transesterification of sunflower oil with ethanol in the presence of $\mathrm{NaOH}$ were compared. The reaction temperature, the amount of $\mathrm{NaOH}$, and the ethanol/oil molar ratio were modified to find the optimal conditions. This study determined that if the ethanol/oil molar ratio is $12: 1$ and the amount of $\mathrm{NaOH}$ is $1.25 \mathrm{wt} . \%$, the reaction would reach a $98 \%$ yield in temperature ranges from 25 to $75{ }^{\circ} \mathrm{C}$. They also concluded that the Box-Behnken and face-centered composite methods are recommended to reduce the number of experiments and predict reliable results in the optimization of the biodiesel 
production process. Some examples that used other experimental designs are exposed in Table 1.

Table 1. Optimization of biofuel production with different designs of experiments.

\begin{tabular}{|c|c|c|c|c|c|}
\hline Oil System & Design of Experiment & Optimal Conditions & Yield (\%) & Catalysts & Reference \\
\hline Sunflower Oil & $\begin{array}{c}\text { Box-Behnken, } \\
\text { Face Centered Central } \\
\text { Composite, } \\
\text { Full Factorial }\end{array}$ & $\begin{array}{c}\text { Temperature: } 75^{\circ} \mathrm{C} \\
\text { Ethanol/Oil: } 12: 1 \\
\text { Catalyst loading: } 1.25 \text { wt. } \%\end{array}$ & 97.6 & $\mathrm{NaOH}$ & [56] \\
\hline Castor Oil & Taguchi & $\begin{array}{c}\text { Time: } 60 \mathrm{~min} \\
\text { Temperature: } 50{ }^{\circ} \mathrm{C} \\
\text { Catalyst loading: } 1 \mathrm{wt} . \% \\
\text { Methanol/oil: } 20: 1 \\
\text { Agitation speed: } 700 \mathrm{rpm}\end{array}$ & 90.83 & $\mathrm{H}_{2} \mathrm{SO}_{4}$ & [57] \\
\hline $\begin{array}{l}\text { Mahogany Seed } \\
\text { Oil }\end{array}$ & Taguchi & $\begin{array}{l}\text { Methanol/oil: } 9: 1 \\
\text { Catalyst loading: } 0.5 \mathrm{wt} . \% \\
\text { Temperature: } 60{ }^{\circ} \mathrm{C} \\
\text { Agitation speed: } 300 \mathrm{rpm}\end{array}$ & 96.8 & $\mathrm{NaOH}$ & [58] \\
\hline $\begin{array}{c}\text { Ceiba Pentandra } \\
\text { Oil }\end{array}$ & Box-Behnken & $\begin{array}{l}\text { Methanol/oil: } 60: 1 \\
\text { Catalyst loading: } 0.84 \mathrm{wt} . \% \\
\text { Time: } 6.46 \mathrm{~min} \\
\text { Agitation speed: } 800 \mathrm{rpm} \\
\text { Microwaved to } 100{ }^{\circ} \mathrm{C}\end{array}$ & 95.42 & $\mathrm{KOH}$ & [59] \\
\hline Sardine Fish Oil & Box-Behnken & $\begin{array}{l}\text { Temperature: } 150{ }^{\circ} \mathrm{C} \\
\text { Methanol/oil: } 6: 1 \\
\text { Catalyst loading: } 1.25 \text { wt. } \% \\
\text { Time: } 25 \text { min } \\
\text { Methanol/oil: } 10.44: 1\end{array}$ & 98.1 & $\mathrm{KOH}$ & {$[60]$} \\
\hline Karanja Oil & Box-Behnken & $\begin{array}{c}\text { Catalyst loading: } 1.22 \mathrm{wt} . \% \\
\text { Time: } 90.78 \mathrm{~min} \\
\text { Temperature: } 66.8^{\circ} \mathrm{C}\end{array}$ & 91.05 & $\mathrm{KOH}$ & [61] \\
\hline $\begin{array}{l}\text { Mixture of } \\
\text { Pongamia and } \\
\text { Neem Oils }\end{array}$ & Central Composite & $\begin{array}{l}\text { Time: } 77 \mathrm{~min} \\
\text { Catalyst loading: } 0.67 \mathrm{wt} . \% \\
\text { Methanol/oil: } 6: 1\end{array}$ & 86.3 & $\mathrm{NaOH}$ & [62] \\
\hline
\end{tabular}

To avoid or minimize the inconveniences of the conventional homogenous catalysts, the use of heterogeneous catalysts has been proposed, which have shown potential for these reactions. Likewise, it has been considered that these catalysts could be used soon from small agricultural plants to be incorporated into refineries to mix the biodiesel with the conventional diesel loads. The development of heterogeneous catalysts has garnered attention because they are easy to separate by physical methods, low water consumption, they can be used in continuous reactors and reused after being recovered, they are not corrosive, present less sensitive to the presence of water, and are non-hazardous to the environment $[51,63,64]$. However, their catalytic activities remain low compared to homogeneous catalysts due to the amount and strength of active sites and the problems of matter transfer in the three-phase system (catalyst-oil-alcohol). Besides, there may be leaching of active sites or deactivation of sites by $\mathrm{CO}_{2}$ from the air [65]. Consequently, this has motivated different investigations to obtain sufficiently active catalysts that can be recovered as well as the reaction conditions and types of reactors.

Heterogeneous catalysts can have basic or acidic functionalities. The basic solids include a wide variety of catalysts such as alkaline earth, which can be doped with alkali metals, mixed or supported over $\mathrm{Al}_{2} \mathrm{O}_{3}, \mathrm{SiO}_{2}$, and hydrotalcites [66-68]. Additionally, transition metal oxides, zeolites, or activated carbon can also function as catalysts with acidic functionalities [69]. The use of solid catalysts derived from biomass such as diatomic earth, animal bones, seashells, or eggshell, has been proposed as more ecological alternatives [70]. This vast catalog of catalysts allows choosing the best system depending on the nature and quality of the oil, its availability, and the economic situation of the biorefinery or rural plant. 
As alkaline earth metal oxides have presented relative advantages over the other materials, they can be potentially used due to their availability, price, and catalytic activity. Hence, this work focuses on summarizing and analyzing the most important parameters that involve $\mathrm{MgO}, \mathrm{CaO}, \mathrm{SrO}$, and $\mathrm{BaO}$, such as source, synthesis method, thermal treatment, and its effect on the basicity of the active sites and operational conditions used.

\section{Alkaline Earth Metal Catalysts}

Alkaline-earth metal oxides, such as $\mathrm{CaO}, \mathrm{MgO}, \mathrm{SrO}$, and $\mathrm{BaO}$, have been well known to be basic solid catalysts [31,68]. It has been agreed that the active sites of these materials are the surface basic sites of the catalysts for the transesterification of triglycerides so that the number of sites and their basic strength are determinants in the catalytic activity [71,72]. The basic site is produced by the presence of the surface metal ion that behaves like a Lewis acid and an oxygen ion that behaves like a Brønsted basic site [73]. These catalysts are economical and accessible, recyclable, and non-corrosive. However, these catalysts can be deactivated because basic sites may be poisoned by strong adsorption of FFA and water at the surface sites. Therefore, the activity decreases in each reuse cycle because of the saponification side reactions [42]. According to different studies, the basic strength of alkaline earth oxides has been determined to follow the following order $\mathrm{BaO}>\mathrm{SrO}>\mathrm{CaO}$ $>\mathrm{MgO}$ [74-76], which has been correlated with catalytic activity in the same order [71,77] as Table 2 shows.

Table 2. Basic strength of the alkaline earth metals oxides obtained by Hammett indicators method [76].

\begin{tabular}{cc}
\hline Catalysts & Basicity \\
\hline $\mathrm{MgO}$ & $8.2 \geq \mathrm{H} \geq 6.8$ \\
$\mathrm{CaO}$ & $15 \geq \mathrm{H} \geq 13.4$ \\
$\mathrm{SrO}$ & $17.2 \geq \mathrm{H} \geq 15$ \\
$\mathrm{BaO}$ & $17.2 \geq \mathrm{H} \geq 15$ \\
\hline
\end{tabular}

Yang et al. [71] compared these metal oxides under the same conditions in the transesterification of rapeseed oil. All catalysts were pretreated at $700{ }^{\circ} \mathrm{C}$ under nitrogen for $2 \mathrm{~h}$, and all the reactions were carried out at $64.5^{\circ} \mathrm{C}$, with $10 \mathrm{wt} . \%$ catalyst, with a methanol/oil ratio of 18:1 for $3.5 \mathrm{~h}$. These authors found the following order in the conversion of oil: $\mathrm{BaO}(86 \%), \mathrm{SrO}(60 \%), \mathrm{CaO}(58 \%)$, and $\mathrm{MgO}(<5 \%)$. Also, they correlated it with the ionic radius and alkalinity of the metals. In this work, they concluded that $\mathrm{BaO}$ is a strong base, providing a higher catalytic activity than the others. However, this material can be diluted in methanol and could generate toxic barium compounds [78]. In contrast, $\mathrm{SrO}$ does not present these problems. Nevertheless, it is deactivated by contact with $\mathrm{CO}_{2}$ and ambient moisture, and it is easily leached in the reaction medium [67]. Finally, despite having lower activities, the $\mathrm{CaO}$ and $\mathrm{MgO}$ oxides are cheaper than $\mathrm{SrO}$ and $\mathrm{BaO}$ and can be simply obtained from natural sources. Plus, they are non-toxic and have low solubility with methanol.

\section{1. $\mathrm{MgO}$}

Hattori [79] mentioned that the basic sites of solid $\mathrm{MgO}$ catalysts are generated at high calcination temperatures $(1200 \mathrm{~K})$ to remove adsorbed water and carbon dioxide and obtain a surface free of carbonates, hydroxides, and peroxides. Besides, the severity of the thermal treatment, i.e., the calcination process, directly influences the nature of the sites: at low temperatures $\left(\sim 430^{\circ} \mathrm{C}\right)$, the sites are weak, while at high temperatures $\left(\sim 930^{\circ} \mathrm{C}\right)$, the sites they will be strong [80]. This is due to the changes in the arrangement of the surface atoms and the crystal size that is formed during the heat treatment that results in changes in the coordination numbers of the metal atoms and, therefore, in their basicity. In general, it has been proposed that high temperatures generate pairs of $\mathrm{M}^{2+}$ and $\mathrm{O}^{2-}$ ions (where $\mathrm{M}$ can be $\mathrm{Ca}, \mathrm{Mg}$, $\mathrm{Sr}$ or $\mathrm{Ba}$ ) in different coordinates, which are strong basic 
sites and are located in the corners, edges, or on surfaces with high Miller indexes. The thermal treatment on these materials has a direct effect on crystallinity, the surface area, and the basic resistance of the catalytic sites determined with temperature-programmed desorption of $\mathrm{CO}_{2}\left(\mathrm{CO}_{2}\right.$-TPD) [81].

According to Gryglewicz [78], the reaction mechanism of triglycerides on a heterogeneous catalyst is based on the nucleophilic and electrophilic characteristics of the carbonyl group of triglycerides and alcohol, similar to those that occur in the presence of a homogeneous basic catalyst. FFA reactions can be converted to a carboxylate salt and then react with an alkyl halide through the concerted SN2 mechanism. The reaction pathway of the transesterification of triglycerides in the presence of heterogeneous catalysts can be described with an Eley-Rideal mechanism involving an active site or also with a LangmuirHinshelwood mechanism involving two active sites. In the Eley-Rideal mechanism, the alcohol must be activated through the surface basic site. The basic site, $\mathrm{O}^{2-}$, extracts $\mathrm{H}^{+}$ from the alcohol, while the R-O- ( $\mathrm{R}$ being any hydrocarbon chain) group is adsorbed in the metallic site forming an active anionic alkoxide. This activation process in the presence of weak basic sites is considered a crucial stage. Subsequently, the carbonyl atom of the triglyceride attracts the anionic alkoxide group to form a tetrahedral intermediate. Then, this intermediate takes the $\mathrm{H}^{+}$from the surface basic site, and it is rearranged to form the ester. For their part, Hattori et al. [75] detailed the reaction pathway using a Langmuir-Hinshelwood mechanism (Figure 3). This mechanism starts with the activation of the alcohol on the surface basic site as it has been previously described. However, it is proposed that the adjacent metallic site adsorbs the carbonyl group and creates a cationic complex. Afterward, the activated alkoxide performs the nucleophilic attack on carbonyl and adds the alcohol chain to the hydrocarbon chain to create a tetrahedral intermediate. The organic molecule is desorbed through the arrangement of the charges of oxygen attached to carbonyl in such a way it generates an ester and a diglyceride. This stage is the crucial one for catalysts with strong basic sites. Furthermore, this stage is repeated two more times with the diglyceride and the monoglyceride to create three molecules of ester and one of glycerol.

$\mathrm{MgO}$ was one of the first studied heterogeneous catalysts due to the presence of basic sites on its surface and to its low solubility in the reaction medium. It has been proposed as an industrial catalyst for transesterification [66,82]. $\mathrm{MgO}$ has been tested in the transesterification of soybean, sunflower, and rapeseed oil in supercritical conditions [83]. The oils entirely showed an increment in the yield of FAME when the methanol/oil ratio reached $41: 1$ at $252{ }^{\circ} \mathrm{C}$ and $24 \mathrm{MPa}$. In the same way, an increased yield of FAME was observed when the temperature changed from 192 to $252{ }^{\circ} \mathrm{C}$. In this catalytic test, the soybean oil transesterification was higher than the other oils due to its lower FFA content. Hence, high FFA concentration decreases the catalytic activity of $\mathrm{MgO}$. To increase the basicity of $\mathrm{MgO}$, it was proposed to impregnate it with $\mathrm{KOH}(10,20$, and $30 \mathrm{wt}$ \% $\mathrm{KOH})$ and test it using the transesterification of canola oil [84]. This research got the following optimal results: $20 \mathrm{wt}$ \% of $\mathrm{KOH}$ over $\mathrm{MgO}$, alcohol/oil = 6:1, $3 \mathrm{wt}$.\% of catalysts, and $9 \mathrm{~h}$ reaction at $65^{\circ} \mathrm{C}$. As characterization results indicated, the basicity of the catalysts changes with the impregnation of $\mathrm{KOH}$. Also, the formation of $\mathrm{K}_{2} \mathrm{CO}_{3}$ was observed when $\mathrm{KOH}$ content was higher than $10 \mathrm{wt}$ \% due to the interaction between the hydroxide and the magnesia, which reduces the strength of the $\mathrm{Mg}-\mathrm{O}$ bonds and avoids the deactivation by $\mathrm{CO}_{2}$. However, high amounts of superficial $\mathrm{KOH}$ crystallites were produced and are easily leached. 


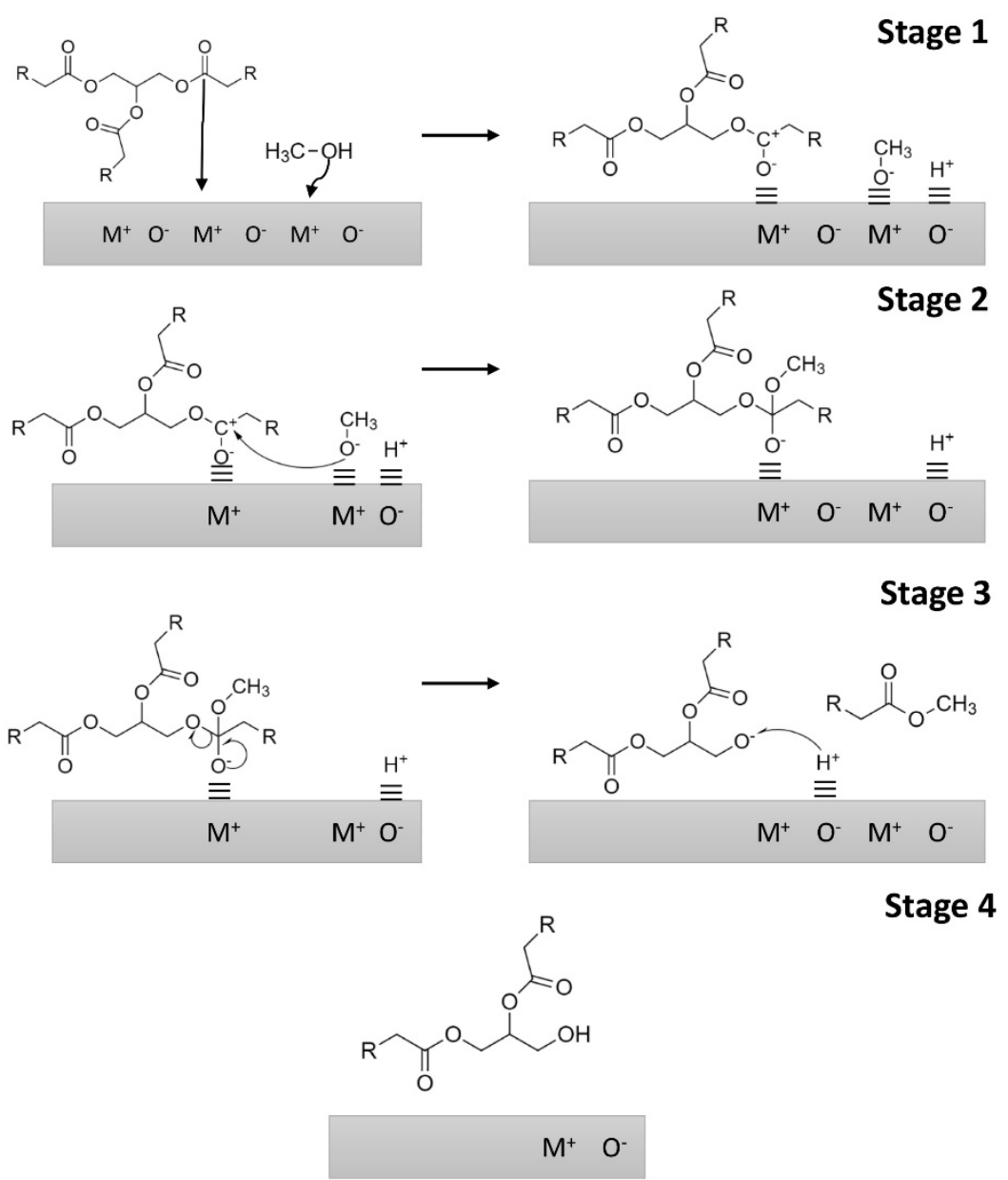

Figure 3. Diagram of the Langmuir-Hinshelwood reaction of a heterogeneous catalyst for the activation of the alcohol and transesterification of the triglyceride. $\mathrm{M}$ is the metallic site and $\mathrm{O}$ is the superficial oxygen $[30,75]$.

$\mathrm{MgO}$ nanoparticles have shown that less $\mathrm{CO}_{2}$ could be chemisorbed compared to bulk-like catalysts and have been synthesized by different methods that directly influence the morphology of the material and, consequently, in their reactivity. The studies have coincided that the (111) plane in $\mathrm{MgO}$ is composed of monolayers of cations and anions alternated, which generates a strong electrostatic field perpendicular to it [85-88]. This high surface energy polar surface enhances the methanol decomposition, promoting its activation and, consequently, the transesterification yield [86]. In a comprehensive study, Verziu et al. [89] proposed an efficient and simple method to generate highly active $\mathrm{MgO}$ nanosheets that were tested in the transesterification of rapeseed and sunflower oil. They compared three catalysts with one plane exposed the most: (111) with a lattice spacing of $0.25 \mathrm{~nm}$, (110) with $0.148 \mathrm{~nm}$, and (100) with $0.21 \mathrm{~nm}$. The $\mathrm{CO}_{2}-\mathrm{TPD}$ analysis showed that (111) catalysts presented more basic sites than the other two. Nevertheless, these last showed the strongest basic sites. The catalytic evaluation was carried out with oil to methanol ratio of 1:4,300 mg of catalysts at 583 and $773 \mathrm{~K}$. The effect of heating and mixing was compared using autoclave and microwave, and mechanical stirring and ultrasound, respectively. The sunflower transesterification conversion and yields were higher than rapeseed oil due to its lower FFA content. In sunflower transesterification, the (111) plane exposed catalyst showed higher FAME yields and conversion than the other two catalysts. The best performance of this catalyst was achieved at $500{ }^{\circ} \mathrm{C}$ in microwave conditions. This catalyst also showed stability and capability to be used in six or seven cycles without any reactivation. Nonetheless, if ultrasound conditions are used, the leach of $\mathrm{MgO}$ increases noticeably. 
In a more recent study, goat fat treatment was assessed in the presence of $\mathrm{MgO}$ nanoparticles, which reported a yield of $93 \%$ at $70{ }^{\circ} \mathrm{C}$ with a methanol/oil ratio of $12: 1$, a catalyst loading of $1 \mathrm{wt} . \%$ in $3 \mathrm{~h} \mathrm{[90].} \mathrm{Nevertheless,} \mathrm{it} \mathrm{was} \mathrm{observed} \mathrm{that,} \mathrm{when} \mathrm{the}$ catalyst content was increased to $1.25 \mathrm{wt} . \%$, the yield decreased to $90 \%$, possibly due to the $\mathrm{MgO}$ nanoparticle agglomeration, which resulted in the loss of active surface area. $\mathrm{MgO}$ nanoparticles have also been tested in wasted cooking oil [91]. In this work, it was found that $15 \mathrm{~nm} \mathrm{MgO}$ crystals, obtained from magnesium acetate (calcined at $600{ }^{\circ} \mathrm{C}$ ), is enough to attain a biodiesel yield of $80 \%$ at $60^{\circ} \mathrm{C}$, with a methanol/oil ratio of $10: 1$ and catalyst $2 \mathrm{wt} . \%$ in the oil. These studies are summarized in Table 3.

Table 3. Summary of some transesterification tests using $\mathrm{MgO}$ as a catalyst.

\begin{tabular}{|c|c|c|c|c|c|c|c|}
\hline Catalyst & Oil & $\begin{array}{c}\text { Temperature } \\
\left({ }^{\circ} \mathrm{C}\right)\end{array}$ & Alcohol/Oil & $\begin{array}{c}\text { Catalysts } \\
\text { Loading (wt.\%) }\end{array}$ & $\begin{array}{l}\text { Time } \\
\text { (Min) }\end{array}$ & Yield (\%) & Reference \\
\hline $\mathrm{MgO}$ & $\begin{array}{l}\text { Sunflower } \\
\text { Soybean } \\
\text { Rapeseed }\end{array}$ & $\begin{array}{c}252 \\
\text { (at } 100 \mathrm{MPa})\end{array}$ & $41: 1$ & 3 & 20 & $\begin{array}{c}98 \\
100 \\
95\end{array}$ & [83] \\
\hline $\begin{array}{c}\mathrm{KOH} / \mathrm{MgO}(20 \\
\text { wt. } \% \mathrm{KOH})\end{array}$ & Canola & 65 & $6: 1$ & 3 & 540 & 95 & [84] \\
\hline $\begin{array}{c}\text { Copolymer } \\
\text { templated MgO } \\
(\mathrm{PDMS}-\mathrm{PEO})\end{array}$ & Canola & 190 & $20: 3$ & 3 & 120 & 98.2 & [81] \\
\hline MgO nanoparticles & Goat fat & 70 & $12: 1$ & 1 & 180 & 93 & [90] \\
\hline MgO nanoparticles & $\begin{array}{c}\text { Wasted } \\
\text { cooking oil }\end{array}$ & 60 & $10: 1$ & 2 & 120 & 80 & [91] \\
\hline
\end{tabular}

As an alternative, the use of natural minerals such as hydrotalcite and dolomite has been proposed so they can be used as catalysts since they are composed of aluminum and magnesium carbonates $\left(\mathrm{Mg}_{6} \mathrm{Al}_{2} \mathrm{CO}_{3}(\mathrm{OH})_{16} \cdot 4\left(\mathrm{H}_{2} \mathrm{O}\right)\right)$; and calcium and magnesium carbonates $\left(\mathrm{CaMg}\left(\mathrm{CO}_{3}\right)_{2}\right)$, respectively $[92,93]$. These calcined compounds have shown an acceptable catalytic yield. It has been recently proposed the use of hydrotalcites modified with $\mathrm{K}^{+}$, which were studied by Zhang et al. [94]. After the optimization tests, it was determined that the transesterification of rapeseed oil could achieve a biodiesel yield of $99 \%$ in the presence of a hydrotalcite impregnated by $\mathrm{K}_{2} \mathrm{CO}_{3}\left(\mathrm{~K}^{+} /\right.$hydrotalcite load of $6.25 \%$ ). The reaction conditions were alcohol/oil ratio of $12: 1,60{ }^{\circ} \mathrm{C}$, a catalyst loading of 2 wt. \% with oil, and ultrasonic stirring $(40 \mathrm{kHz})$ for one hour. The authors found that when the hydrotalcite is impregnated with $\mathrm{K}_{2} \mathrm{CO}_{3}$, the $\mathrm{K}^{+}$introduces into the lattice of the support. This results in the formation of compounds such as $\mathrm{K}_{2} \mathrm{O}, \mathrm{Al}-\mathrm{O}-\mathrm{K}$, and $\mathrm{Mg}-\mathrm{O}-\mathrm{K}$ that are highly basic, as $\mathrm{XRD}$ and $\mathrm{CO}_{2}$-TPD experiments showed. Thus, the activity of the doped hydrotalcite was noticeably higher than non-impregnated hydrotalcite.

In a comprehensive study, Jindapon et al. [95] determined the role of $\mathrm{MgO}$ in the use of natural dolomite $\left(56.6 \mathrm{wt} . \% \mathrm{CaCO}_{3}, 43.2 \mathrm{wt} . \% \mathrm{MgCO}_{3}\right.$ ) for the transesterification of palm oil refined at $60^{\circ} \mathrm{C}$. The reaction yields of the calcined dolomite at $650{ }^{\circ} \mathrm{C}, 700{ }^{\circ} \mathrm{C}$, and $800{ }^{\circ} \mathrm{C}$ were compared to those of $\mathrm{CaO}$ calcined at $800^{\circ} \mathrm{C}$ as reference. The results showed that both, $\mathrm{CaO}-800$ and $\mathrm{CaMgO}-800$, had the highest density of surface basic sites in the $\mathrm{CO}_{2}$-TPD tests, which were then correlated with higher catalytic activity. This work found that complete carbonate removal from $\mathrm{Ca}$ and $\mathrm{Mg}$ oxides of natural sources significantly improved the catalytic activity, which was achieved with the annealing of the material at $800{ }^{\circ} \mathrm{C}$ using a heating rate of $3{ }^{\circ} \mathrm{C} \cdot \mathrm{min}^{-1}$. For dolomite and seashells (97 wt. $\%$ ), it was proposed that the $\mathrm{CaO}$ crystallites size would influence the FAME reaction rate and yield. A shrink-core thermal decomposition model explained this correlation based on the results obtained by X-ray photoelectron spectroscopy (XPS) since they showed that $\mathrm{CaO}$ creates base clusters $(40 \mathrm{~nm})$ when the calcination temperature is increased. Nevertheless, in $\mathrm{CaMgO}-800$, a faster formation of $\mathrm{MgO}$ was observed, which delays the formation and 
agglomeration of $\mathrm{CaO}$ clusters, leaving remnants of carbonate and hydroxide compounds. The presence of a greater amount of $\mathrm{MgO}$, when compared to $\mathrm{CaO}$, provides surface acidity, which in turn decreases the hydroxylation and carbonation degree of the produced $\mathrm{CaO}$ (Figure 4).

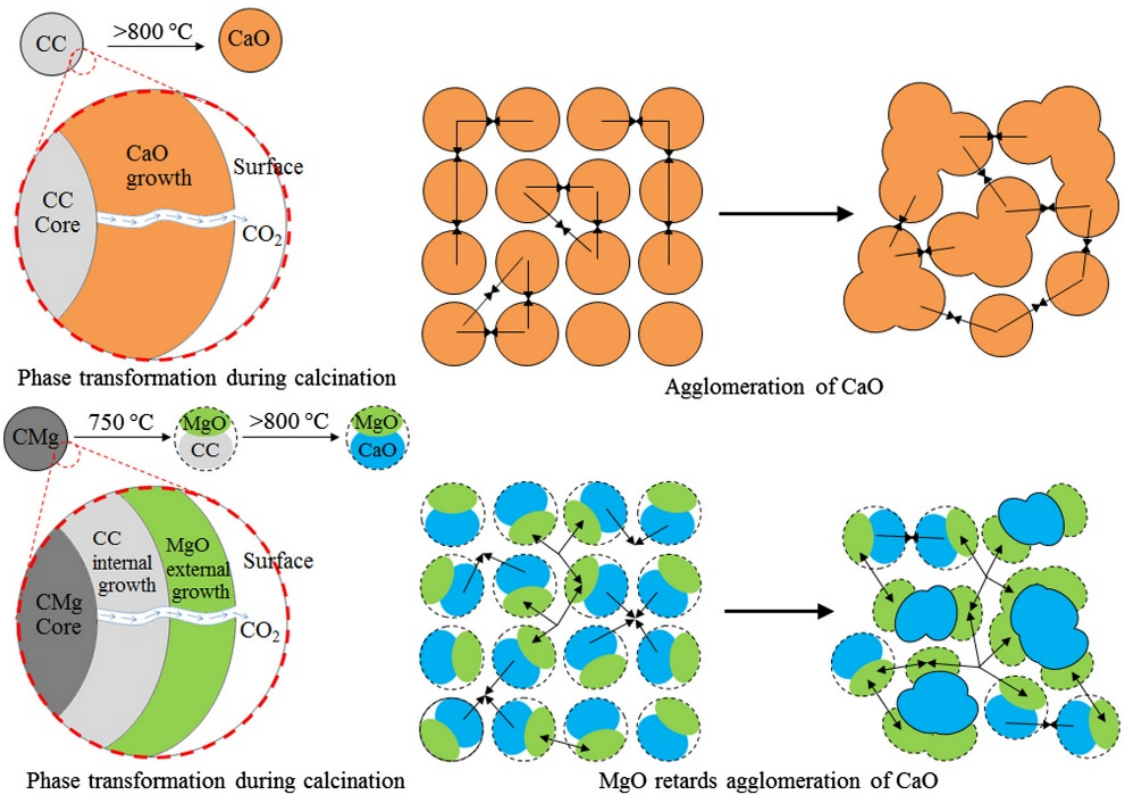

Figure 4. Proposed model of the phase transformation for the thermal decomposition of calcite and dolomite. Reproduced with permission from [95]. Copyright Elsevier, 2018.

Diatomaceous earth has also been proposed as a natural alternative to enduring alkaline and alkaline earth metals $[95,96]$. One advantage of these natural materials is that they are highly porous; therefore, they have high surface areas due to their silica content. To improve the yield of catalysts obtained from this material, Modiba et al. [97] impregnated diatomite with potassium at different $\mathrm{KOH}$ /diatomite ratios and tested them with vegetable oil, using an experimental Central Composite design. When impregnated potassium is calcined, $\mathrm{K}_{2} \mathrm{O}$ is generated in the structural matrix of the diatomite, which results in increased basicity and, thus, and increased catalytic activity. Therefore, it was determined that the highest biodiesel yield $(90 \%)$ was obtained in $4 \mathrm{~h}$ with a methanol/oil mass ratio of 30, a catalyst/oil ratio of 5 and $75^{\circ} \mathrm{C}$. Moreover, it was concluded that an increment in the methanol/oil ratio caused glycerolysis and formed monoglycerides, which in turn decreased reaction yield. Additionally, this catalyst showed a capacity of being reused up to three times with only slight changes in reaction yield.

Conversely, Rabie et al. [96] impregnated $\mathrm{CaO}$ and $\mathrm{MgO}$ in diatomite to increase basicity. Scanning electron microscopy (SEM), X-ray diffraction (XRD), and Fourier Transform infrared spectroscopy (FTIRS) analysis showed that these alkaline oxides coated the diatomite and, thus, reduced the pore diameter and incremented the surface area. Furthermore, part of these does not impregnate diatomite but precipitates and contributes to basic sites. In reaction tests, it was observed that the optimal conditions for the $\mathrm{CaO} / \mathrm{MgO}$ catalyst with diatomite were methanol/oil ratio of $15: 1$, at $90{ }^{\circ} \mathrm{C}$, with $6 \mathrm{wt} . \%$ catalyst, which attained a $96.5 \%$ yield at 120 min of reaction. This catalyst can be used for up to seven runs.

\section{2. $\mathrm{CaO}$}

$\mathrm{CaO}$ has been one of the most used materials since it is inexpensive and comes from different natural sources like limestone, dolomite, bones, seashells, eggshells, calcium nitrate, calcium acetate, and calcium carbonate. In 2008, Liu et al. [98] used $\mathrm{CaO}$ to study the effect of the methanol/oil molar ratio, temperature, catalysts amount, and water 
concentration in the transesterification of soybean oil. In this work, the authors concluded that the amount of water is an important factor in the transesterification reactions. Hence, they proposed a reaction mechanism considering the presence of water. They explained that the $\mathrm{O}^{2-}$ from $\mathrm{CaO}$ surface would extract $\mathrm{H}^{+}$from water to generate a superficial $\mathrm{OH}^{-}$group that may extract the $\mathrm{H}^{+}$from methanol to form a methoxide anion $\left(\mathrm{CH}_{3} \mathrm{O}^{-}\right)$. The methoxide anion is considered to be highly active in the transesterification reactions due to its alkaline character. Hence, the $\mathrm{CH}_{3} \mathrm{O}^{-}$group attacks the carbonyl group from a triglyceride to generate a tetrahedral intermediate that will take adsorbed $\mathrm{H}^{+}$group from de $\mathrm{CaO}$ surface. Finally, the intermediate will rearrange itself to produce FAME molecules and glycerol. As it was concluded, water could assist the generation of methoxide ions; nonetheless, if the water content exceeds the $2.8 \mathrm{wt} . \%$ in the oil, the FAME would be hydrolyzed under basic conditions, and FFA could be formed. Concerning the reaction conditions, their results showed that a molar ratio methanol/oil of 12:1 with 8 wt.\% of catalysts at $65{ }^{\circ} \mathrm{C}$ and a maximum of $2.03 \%$ of water, the transesterification of soybean oil might reach a FAME yield of $95 \%$.

Kouzu et al. [99] compared the catalytic activity of $\mathrm{CaCO}_{3}, \mathrm{CaO}$ synthesized from the calcination of $\mathrm{CaCO}_{3}$ in an inert atmosphere, and in air and calcium hydroxide obtained from the hydration of $\mathrm{CaO}$ in the transesterification of soybean oil. The obtained data showed that $\mathrm{CaO}$ calcined in an inert atmosphere has a higher activity than $\mathrm{Ca}(\mathrm{OH})_{2}, \mathrm{CaO}$ calcined in air, and $\mathrm{CaCO}_{3}$, as Figure 5 shows.

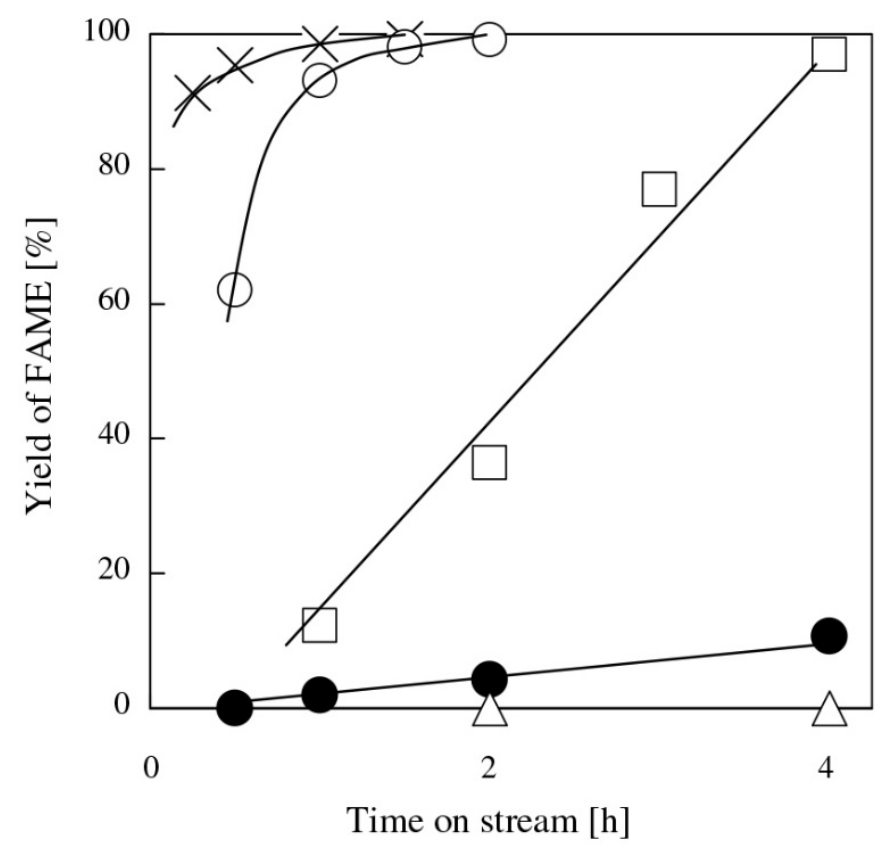

Figure 5. Yield of FAME for transesterification of soybean oil with methanol: $(\mathrm{O}) \mathrm{CaO} ;(\square) \mathrm{Ca}(\mathrm{OH})_{2}$; $(\Delta) \mathrm{CaCO}_{3} ;(\mathrm{X}) \mathrm{NaOH} ;(\bullet) \mathrm{CaO}$-Air. Reproduced with permission from [99]. Copyright Elsevier, 2008.

Based on these results, it was proposed that alkaline sites formed on the $\mathrm{CaO}$ surface were susceptible to moisture and atmospheric $\mathrm{CO}_{2}$; therefore, they are deactivated when exposed to air. For this result discussion, the authors state that there is a possible change in the reaction order from zero to first order while the reaction is happening when using inert calcined $\mathrm{CaO}$ as a catalyst. In this same publication, they included $\mathrm{CaO}$ yield in the transesterification of waste cooking oil. This type of oil is characterized by its water and free fatty acid contents, which poison the basic sites. Despite this, it was found that $\mathrm{CaO}$ can also be used for this type of oil since it attains a 99\% yield after a $2 \mathrm{~h}$ reaction. Nevertheless, the saponification of part of the catalyst was observed, which decreased its activity. 
Afterward, Kouzu and Hidaka [65] published a comprehensive review on the use of $\mathrm{CaO}$ in the transesterification of vegetable oils, for which they examined the surface base properties, preparation, deactivation, modifications, and uses of this oxide. Reading this document is recommended to have a better understanding of the $\mathrm{CaO}$ system. One of the most important elements in this work is the analysis of the research carried out by lizuka et al. [100], who explained the Lewis acidity of the $\mathrm{Ca}^{2+}$ cation, which is weak due to its electronegativity. Based on this, conjugated oxygen anions $\mathrm{O}^{2-}$ show strong basicity. Moreover, it was concluded that isolated $\mathrm{OH}^{-}$groups serve as basic sites according to the obtained results for FTIRS and XPS. Additionally, through $\mathrm{CO}_{2}-\mathrm{TPD}$, it was determined that $\mathrm{CaO}$ must be calcined at high temperatures $\left(>630^{\circ} \mathrm{C}\right)$ to activate the basic sites. Compared to $\mathrm{SrO}$ and $\mathrm{BaO}, \mathrm{CaO}$ has a larger number of basic sites per mass unit, even though $\mathrm{SrO}$ and $\mathrm{BaO}$ are stronger than those in $\mathrm{CaO}$. However, $\mathrm{SrO}$ tends to lixiviate easier in reaction products than $\mathrm{CaO}$; therefore, the latter has a higher capacity for reuse. In this same review, the authors mention that during the reaction, calcium may transform in different active species. It can react with methanol to produce calcium methoxide and with glycerol to form calcium glyceroxide $\left(\mathrm{Ca}\left[\mathrm{O}(\mathrm{OH})_{2} \mathrm{C}_{3} \mathrm{H}_{5}\right]_{2}\right)$, which is less active than $\mathrm{CaO}$ [101]. However, this compound can reversibly react with methanol resulting in $\mathrm{Ca}$ organic species $\left(\mathrm{CH}_{3} \mathrm{O}-\right.$ $\left.\mathrm{Ca}-\mathrm{O}(\mathrm{OH})_{2} \mathrm{C}_{3} \mathrm{H}_{5}\right)$, which also possess weak basic sites and, thus, are less active than $\mathrm{CaO}$ [102]. Therefore, calcium glyceroxide is a precursor of active species. Nevertheless, since that part of $\mathrm{CaO}$ is lixiviated during the transesterification reaction and the formation of Ca species, the homogeneous contribution increases to high conversions provoking that yield remains approximately 95\%. Finally, this review concluded that the main problems to overcome for $\mathrm{CaO}$ use are the protection of basic sites from $\mathrm{CO}_{2}$ and moisture and the improvement of this catalyst by designing materials that minimize the lixiviation of the active phase. Hence, in work published in 2017, Kouzu et al. [102] proposed to protect the limestone with biodiesel during the grinding process to avoid the pollution of active sites with moisture and $\mathrm{CO}_{2}$. This new treatment was tested in the transesterification of used oil at a pilot plant scale. The results indicated that $95 \%$ of FAME was attained after $2 \mathrm{~h}$, at $60{ }^{\circ} \mathrm{C}$ with $2 \mathrm{wt}$ \% catalyst, i.e., the protection of active sites was efficient.

Based on this, some research has focused on the combination of $\mathrm{CaO}$ with other metals and natural sources of $\mathrm{CaO}$. To increment the catalyst basicity, doping with alkaline metals, such as $\mathrm{Li}, \mathrm{Na}$, or $\mathrm{K}$, has been proposed [67,74]. Watkins et al. [74] proposed that doping oxide alkaline earth catalysts with alkaline metals ( $\mathrm{Li}$ ) produces a network exchange from $\mathrm{M}^{2+}$ to $\mathrm{M}^{+}$, which creates anionic $\mathrm{O}^{-}$vacancies during calcination. Thereby, the reaction of $\mathrm{M}^{+}$electron-deficient species with $\mathrm{CaO}$ increases the surface defects which, in the presence of water, forms - $\mathrm{OH}$ groups and, thus, increases the basicity. Meher et al. [103] reported the catalytic activity of $\mathrm{CaO}$ doped with alkaline metals ( $\mathrm{Li}, \mathrm{Na}, \mathrm{K}$ $1.25 \mathrm{wt} . \%)$ in the transesterification of karanja oil. These materials showed activity and basicity in the following order: $\mathrm{Li} / \mathrm{CaO}>\mathrm{Na} / \mathrm{CaO}>\mathrm{K} / \mathrm{CaO}$. This group proposed that the smaller the alkaline ion, the simpler it will be for it to enter the network of the alkaline earth oxide and promote the oxygen vacancies. Furthermore, the group included the optimization study of the $\mathrm{Li} / \mathrm{Ca}$ catalyst for which the optimal conditions of karanja oil were determined: FAME yield of $94 \%$ with methanol/oil molar ratio of 12:1, 2 wt. $\%$ of catalyst, and $65{ }^{\circ} \mathrm{C}$ for $8 \mathrm{~h}$. Based on these results, the Li-CaO catalyst was tested in the karanja and jatropha oil transesterification [104]. This research found that the minimal concentration of impregnated lithium was $1.75 \mathrm{wt} . \%$ in order to attain an almost total conversion of both oils in $2 \mathrm{~h}$ at $65^{\circ} \mathrm{C}$, with a methanol/oil molar ratio of 12:1. Moreover, $\mathrm{KF} / \mathrm{CaO}$ catalysts have been studied with chinese tallow tree oil showing yields of more than $96 \%$ in $3 \mathrm{~h}$ at $70{ }^{\circ} \mathrm{C}$, with a methanol/oil ratio of 9:1 and $5 \mathrm{wt}$.\% catalyst [105]. Kumar et al. [106] studied $\mathrm{K} / \mathrm{CaO}\left(1.5-5.5 \%\right.$ of $\left.\mathrm{K}^{+}\right)$in the transesterification of used cotton oil, karanja and jatropha. The results indicated that charging the catalyst with $3.5 \mathrm{wt} \%$ of potassium was enough to attain a FAME yield close to $98 \%$. Even at higher concentrations, there is no increase in basic sites. The optimal conditions were $65^{\circ} \mathrm{C}$, with $7.5 \mathrm{wt} . \%$ catalyst and a methanol/oil ratio of 12:1. To carry out a more exhaustive comparison for the alkaline 
metal impregnation, $\mathrm{Li}, \mathrm{Na}$, and $\mathrm{K} / \mathrm{CaO}$ were tested, and $\mathrm{Li} / \mathrm{CaO}$ was found to be the most active. Nevertheless, it also showed a higher level of lixiviation in biodiesel, while the lixiviation level of $\mathrm{K} / \mathrm{CaO}$ was lower. Table 4 summarizes these results.

Table 4. Summary of some transesterification tests using doped $\mathrm{CaO}$ as a catalyst.

\begin{tabular}{|c|c|c|c|c|c|c|c|}
\hline Catalyst & Oil & $\begin{array}{c}\text { Temperature } \\
\left({ }^{\circ} \mathrm{C}\right)\end{array}$ & Alcohol/Oil & $\begin{array}{c}\text { Catalysts } \\
\text { Loading (wt.\%) }\end{array}$ & $\begin{array}{l}\text { Time } \\
\text { (Min) }\end{array}$ & $\begin{array}{l}\text { Yield } \\
(\%)\end{array}$ & Reference \\
\hline $\begin{array}{l}\mathrm{Li}, \mathrm{Na}, \mathrm{K} / \mathrm{CaO} \\
(1.25 \text { wt. } \%)\end{array}$ & Karanja & 65 & $12: 1$ & 2 & 360 & $97-98$ & [103] \\
\hline $\begin{array}{l}\mathrm{Li} / \mathrm{CaO}(1.75 \\
\text { wt.\%) }\end{array}$ & $\begin{array}{l}\text { Karanja and } \\
\text { Jatropha }\end{array}$ & 65 & $12: 1$ & 5 & 120 & 98 & [104] \\
\hline $\mathrm{KF} / \mathrm{CaO}$ & Chinese Tallow Seed & 70 & $9: 1$ & 5 & 180 & 96 & [105] \\
\hline $\begin{array}{c}\mathrm{K} / \mathrm{CaO}(3.5 \\
\left.\text { wt. } \% \mathrm{~K}^{+}\right)\end{array}$ & $\begin{array}{l}\text { Wasted Cotton Oil, } \\
\text { Jatropha and Karanja }\end{array}$ & 65 & $12: 1$ & 7.5 & 75 & 98 & [106] \\
\hline
\end{tabular}

As it has been mentioned, $\mathrm{CaO}$ can be obtained from natural sources such as eggshells since they have $85-95 \%$ of $\mathrm{CaCO}_{3}, 1.4 \%$ of $\mathrm{MgCO}_{3}, 0.76 \%$ phosphates, and $4 \%$ organic matter and other metals like $\mathrm{K}, \mathrm{Na}, \mathrm{Zn}, \mathrm{Mn}, \mathrm{Cu}$, and Fe [107]. In the same way, it has been proposed the use of bone, crustacean exoskeletons, or seashells [108-111]. This alternative emerged as a solution to reduce costs and catalyst complexity so that rural communities or communities with limited resources could have easy access to this technology and create their own biofuel. Wei et al. [112] used eggshells obtained from local bakeries. Eggshells calcined at $800{ }^{\circ} \mathrm{C}$ were tested in the transesterification of soy oil at $65{ }^{\circ} \mathrm{C}$, with a methanol/oil molar ratio of 9:1 in the presence of $3 \mathrm{wt} . \%$ catalyst to attain a $96 \%$ yield in $3 \mathrm{~h}$. Moreover, it is mentioned that, by calcining the used catalyst once again, it can be reused 13-17 times. Ostrich eggshell has also been used to obtain biodiesel. This study carried out by Chen et al. [113] demonstrated that ostrich eggshells calcined at $800{ }^{\circ} \mathrm{C}$ could be used to obtain biodiesel from palm oil. The catalytic tests of this study compared the use of ultrasound with magnetic stirring. The results showed that, by using ultrasound (60\% amplitude), the reaction yield could be improved since the oil is emulsified with methanol. The vibration decreases the boundary layer, i.e., the transport phenomena limitans. Consequently, the contact area between the solid and the reacts increases allowing it to reach the active sites more efficiently. In the same way, using ultrasound increases the reusing capacity of the catalyst. Furthermore, the optimal values of reaction conditions were methanol/oil ratio of 9:1, at $60{ }^{\circ} \mathrm{C}$ and 8 wt.\% catalyst. Tan et al. [114] compared the catalytic activity of ostrich eggshells with that of chicken eggshells, using the surface response method with Taguchi to find the optimal parameters for the transesterification of used cooking oil. 98\% yield was attained when the reaction was performed at $65{ }^{\circ} \mathrm{C}$, with a methanol/oil ratio of 11:1, and 1.5\% w/v CaO obtained from ostrich eggshells. In contrast, chicken eggshells attained a $95 \%$ yield at $65{ }^{\circ} \mathrm{C}$, with a methanol/oil ratio of $10: 1$, using $1.6 \% w / v$ catalyst. Both methods had similar results; however, the authors recommend using the response surface method due to the capacity of having non-linear relations between parameters. Eggshell properties can be improved by combining them with carbon obtained from pyrolysis residues, as shown by Gollakota et al. [115]. This catalyst was tested in the transesterification of used cooking oil, and the best-operating conditions (97\% yield) were at $65{ }^{\circ} \mathrm{C}$, with a methanol/oil ratio of $12: 1$, and 10 wt.\% of catalyst in $3 \mathrm{~h}$. Catalysts of eggshell combined with pyrolysis residue were more active than eggshells alone. In this case, the increase in catalytic activity would be related to an improved surface dispersion of the active phase because eggshells particles were supported on the pyrolytic carbon.

To increase the number of active sites and decrease the lixiviation of $\mathrm{CaO}$ in the reaction medium, it has been proposed the impregnation of $\mathrm{CaO}$ on $\mathrm{Al}_{2} \mathrm{O}_{3}$ or $\mathrm{SiO}_{2}[116,117]$. Swangkeaw et al. [118] compared $\mathrm{CaO} / \mathrm{Al}_{2} \mathrm{O}_{3}$ with $\mathrm{Al}_{2} \mathrm{O}_{3}$ in the transesterification of palm oil in supercritical conditions through the optimization of response surface experiments: 
$285^{\circ} \mathrm{C}, 20 \mathrm{MPa}$, methanol/oil ratio $30: 1$ and residence time of $4.8 \mathrm{~min}$. Moradi et al. [119] carried out a kinetic study using $\mathrm{CaO} / \mathrm{Al}_{2} \mathrm{O}_{3}(40 \mathrm{wt} . \% \mathrm{CaO})$ in the transesterification of soybean oil at $70{ }^{\circ} \mathrm{C}$, with a methanol/oil ratio of $12: 1$ and $6 \mathrm{wt} . \%$ catalyst. At the beginning of the reaction, there is a resistance in the material transfer from methanol to the catalyst. The formation of biodiesel and glycerol improves the mass transfer and, thus, the reaction speed increases. To enhance the texture properties of these catalysts, i.e., increase the surface area, the synthesis of $\mathrm{CaO} / \mathrm{Al}_{2} \mathrm{O}_{3}$ as an aerogel has been proposed $[120,121]$. Kesserwan et al. [120] performed the transesterification of used oil using $\mathrm{CaO} / \mathrm{Al}_{2} \mathrm{O}_{3}$ aerogel. For this work, they studied the $\mathrm{CaO}$ charge effect and concluded that the optimal molar ratio was 3:1 since no soap is formed due to $\mathrm{CaO}$ crystals being smaller than those synthesized by alcogels (i.e., they are more dispersed). Furthermore, it was determined that the optimal experimental conditions (98\% FAME) were $1 \mathrm{wt} . \%$ catalyst at $65{ }^{\circ} \mathrm{C}$ for $4 \mathrm{~h}$, with a methanol/oil ratio of 11:1. Aghilinategh et al. [122] tested $\mathrm{CaO} / \mathrm{TiO}_{2}$ nanocatalyst at supercritical conditions to generate biodiesel from Chlorella vulgaris microalgae biomass. The $\mathrm{CaO}$ was combined with $\mathrm{TiO}_{2}$ by photochemical method since the precursors were mixed and irradiated with UV light. After this process, the catalyst was calcined at $400{ }^{\circ} \mathrm{C}$ for $4 \mathrm{~h}$. The reaction was operated at $260^{\circ} \mathrm{C}$ and $10 \mathrm{MPa}$ in a batch reactor filled with dry microalgae biomass, methanol, and catalyst. Also, they investigated the effect of the addition of water to the reaction system. They found that the addition of $\mathrm{CaO}$ to $\mathrm{TiO}_{2}$ improved the basic sites and the catalytic activity compared to only $\mathrm{TiO}_{2}$. Also, they found that after the reaction, $\mathrm{CaO}$ was not detected in the products. Hence, the photochemical treatment would provide stability to the catalyst. However, since the photochemical $\mathrm{CaO} / \mathrm{TiO}_{2}$ catalyst was not compared with a similar synthesized by a traditional method, the effects of the photochemical treatment are still not clear. Nonetheless, in the reaction performance, they found that the addition of water to the system would be beneficial to the FAMEs yield. They concluded that subcritical water dissolves the biomass and, together with supercritical methanol, helps to break the cellular membrane. Thus, the mass transfer of the triglycerides to the catalytic surface is enhanced.

$\mathrm{CaO}$ has been combined with $\mathrm{CeO}_{2}$ to improve the activity and avoid the leaching of the metal oxides. Thitsartarn and Kawi [123] synthesized $\mathrm{CaO}-\mathrm{CeO}_{2}$ by co-precipitation technique for the transesterification of palm oil. These authors revealed that the molar ratio 1:1 of $\mathrm{Ca}$ and $\mathrm{Ce}$ was more active than $\mathrm{CaO}$ and $\mathrm{CeO}_{2}$ alone. Moreover, when $\mathrm{Ce}$ was in a higher proportion than $\mathrm{Ca}$, the activity decreased. As Raman and XPS results indicated, the high activity of Ca:Ce 1:1 catalyst was attributed to the presence of $\mathrm{Ca}^{2+}$ ions on the surface. When $\mathrm{Ce}^{3+}$ or $\mathrm{Ce}^{4+}$ increase their concentration on the surface, the basic strength was lower than 1:1 Ca:Ce catalyst and $\mathrm{CaO}$ alone. Also, they found that the calcination temperature has an important role in the structure and so in the catalytic activity. At $650{ }^{\circ} \mathrm{C}$ the $\mathrm{Ca}$ atoms substituted the $\mathrm{Ce}$ atoms at the surface, increasing their interactions. Thus, the amount of $\mathrm{Ca}^{2+}$ was maximum at the surface and the activity was higher than at higher or lower temperatures. The interactions between $\mathrm{Ca}$ and $\mathrm{Ce}$ were beneficial to the stability of the catalyst since no lixiviation of the oxides were detected in the products in 10 cycles. Plus, this catalyst showed a biodiesel yield higher than $90 \%$ in 18 cycles. The optimal operational conditions were methanol/oil ratio of $20: 1,85^{\circ} \mathrm{C}, 5 \mathrm{wt} . \%$ of catalysts to oil, $1500 \mathrm{rpm}$ of mechanical stirring speed for $3 \mathrm{~h}$.

The Co-precipitated $\mathrm{CaO}-\mathrm{La}_{2} \mathrm{O}_{3}$ system is known for its acid-base bifunctionality. It has been tested in transesterification of a high FFA content oil such as jatropha oil [124]. Similar to the $\mathrm{CaO}-\mathrm{CeO}_{2}$ system, the $\mathrm{CaO}-\mathrm{La}_{2} \mathrm{O}_{3}$ catalyst synthesized by the co-precipitation method (calcined at $950{ }^{\circ} \mathrm{C}$ ) showed that $\mathrm{Ca}^{2+}$ substitutes the $\mathrm{La}^{3+}$ ions of the lattice. At the atomic ratio $\mathrm{Ca} / \mathrm{La}=8$, the interactions between these two metal oxides provoke that the $\mathrm{CaO}$ crystals grow so that finish well dispersed all over the catalyst. This causes a synergic effect on the Lewis acid character of the $\mathrm{Ca}^{2+}$ and $\mathrm{La}^{3+}$ species, whereas $\mathrm{O}^{2-}$ species present an enhanced basic strength. The optimal biodiesel yield was $98.76 \%$ at $160{ }^{\circ} \mathrm{C}$ with a methanol/oil ratio of $25: 1$ and $3 \mathrm{wt} . \%$ of catalyst for $3 \mathrm{~h}$. This catalyst presented high stability since a low amount of $\mathrm{Ca}^{2+}$ leached into the biodiesel during four cycles. 
However, despite that $\mathrm{Ca} / \mathrm{La}=10$ was not the most active material, it was the more stable and leached only traces of $\mathrm{Ca}$. Hence introducing a small amount of La would improve the catalyst's structure.

\section{3. $\mathrm{BaO}$ and $\mathrm{SrO}$}

As previously mentioned, $\mathrm{SrO}$ and $\mathrm{BaO}$ have a higher activity when compared to $\mathrm{MgO}$ and $\mathrm{CaO}$. Patil et al. [77] compared $\mathrm{BaO}, \mathrm{SrO}, \mathrm{CaO}$, and $\mathrm{MgO}$ in the transesterification of Camelina sativa oil. The investigation results showed in Figure 6 presents the effect of the methanol/oil ratio, temperature, catalyst concentration, and reaction time.
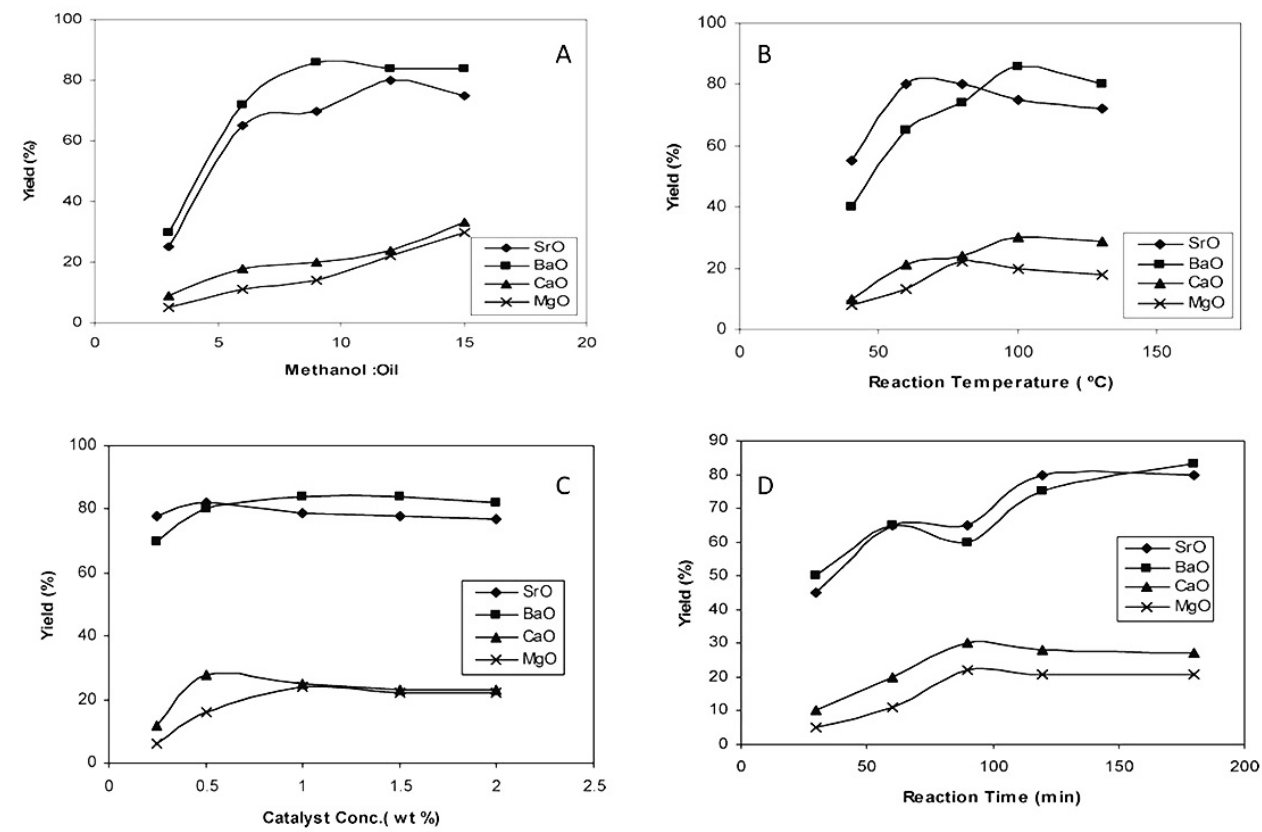

Figure 6. Comparison between the yield of FAME for transesterification of camelina oil with methanol using $\mathrm{SrO}, \mathrm{BaO}, \mathrm{CaO}$ and $\mathrm{MgO}$ : (A) effect of methanol/oil ratio, (B) effect of reaction temperature, (C) effect of catalyst concentration, (D) effect of reaction time. Reproduced with permission from [77]. Copyright American Chemical Society, 2009.

In all tests, $\mathrm{BaO}$ and $\mathrm{SrO}$ attained between $80 \%$ and $90 \%$ yields, while $\mathrm{CaO}$ and $\mathrm{MgO}$ attained between $15 \%$ and $25 \%$ yields. It was concluded that the highest yield was attained after a $3 \mathrm{~h}$ reaction using $1 \mathrm{wt}$.\% catalyst with a methanol/oil ratio of $9: 1$, at $100{ }^{\circ} \mathrm{C}$. In a comparison between $\mathrm{BaO}$ and $\mathrm{CaO}$ in the transesterification of soy oil in supercritical conditions $\left(215^{\circ} \mathrm{C}\right.$, oil/methanol ratio of 3.3:1, $2 \mathrm{~g}$ of catalyst), it was found that, between 15 and $30 \mathrm{~min}, 95 \%$ and 75\% biodiesel yields were attained, respectively [125]. Therefore, the $\mathrm{BaO}$ speed constant was higher than that of $\mathrm{CaO}$. Additionally, the $\mathrm{BaO}$ reaction had an average third-order kinetic (first order to methanol, second-order to triglyceride), with a speed constant of $8.5 \times 10^{-3} \mathrm{~g}^{2} \mathrm{~mol}^{-2} \mathrm{~min}^{-1}$. Moreover, $\mathrm{CaO}$ had an average first-order kinetic (first order in relation to methanol and zero-order for triglyceride), with a speed constant of $4.6 \times 10^{-3} \mathrm{~min}^{-1}$.

The $\mathrm{SrO}$ obtained from the calcination of $\mathrm{SrCO}_{3}$ was compared to homogeneous catalysts, such as $\mathrm{NaOH}, \mathrm{KOH}, \mathrm{NaOCH}_{3}$, and $\mathrm{KOCH}_{3}$, in the transesterification of soy oil (methanol/oil ratio $12: 1,65^{\circ} \mathrm{C}, 3 \mathrm{wt} . \%$ heterogeneous catalyst, $1 \mathrm{wt} . \%$ homogeneous catalyst) $[125,126]$. For this assessment, it was observed that $\mathrm{SrO}$ attained a higher biodiesel yield, $8 \%$ better than that of homogeneous catalysts, at $10 \mathrm{~min}$ of reaction. Moreover, Viola et al. [127] compared $\mathrm{CaO}$ with $\mathrm{SrO}$ and $\mathrm{K}_{3} \mathrm{PO}_{3}$ in the transesterification of used oil with high FFA content $\left(65^{\circ} \mathrm{C}\right.$, methanol/oil ratio $6: 1,5 \mathrm{wt} . \%$ of catalyst). In this study, it was determined that $\mathrm{CaO}(92 \%)$ had a higher FAME yield when compared to the other two catalysts (85\%). Furthermore, the effect on particle size was reported, and it showed that, 
when $\mathrm{CaO}$ is used, the initial speed of fine powder is higher than that when granules are used $(0.5-2 \mathrm{~mm})$. In contrast, when $\mathrm{SrO}$ is used, there was no significant difference between them. This may be due to $\mathrm{SrO}$ having more basic sites than $\mathrm{CaO}$. SrO has also been assessed, with good results, using microwave heating and ultrasonic stirring in the formation of biodiesel from jatropha and castor oil extracted directly from the seeds [128].

The use of SrO has been limited due to its lixiviation tendency in methanol. Consequently, in recent works, combining $\mathrm{SrO}$ with another oxide has been proposed to increase its stability. Ali et al. [129] studied the synthesis of the $\mathrm{SrO} / \mathrm{CaO}$ system (molar ratio 1:6) for the transesterification of jatropha oil with ultrasonic agitation at $65^{\circ} \mathrm{C}$, with a methanol/oil ratio of 10:1 and $6 \mathrm{wt} . \%$ catalyst. Catalysts were impregnated using a $\mathrm{CaO}$ humid impregnation method with strontium nitrate and then calcined at $800^{\circ} \mathrm{C}$. The XRD results showed a high crystallinity in catalysts, with a size of $40-50 \mathrm{~nm}$. Furthermore, the SEM results indicated that catalysts have a homogeneous morphology with particle sizes of $0.2-0.5 \mathrm{~nm}$. The transesterification of jatropha oil attained a $95.4 \%$ yield through ultrasonic stirring, in contrast to the $89.3 \%$ attained with mechanic stirring in $3 \mathrm{~h}$.

One characteristic of the alkaline earth oxides is their low surface area. Therefore, it has been proposed to support them with high surface area acids or neutrals such as $\mathrm{Al}_{2} \mathrm{O}_{3}$ and $\mathrm{SiO}_{2}$ [130]. Moreover, since alkaline earth metal oxides can be fine powders, supporting them would decrease inhalation health risks. Additionally, the main purpose of this alternative is to provide acidic sites to form a bifunctional catalyst. By supporting a basic oxide with other basic oxide or neutral, the activity can increase due to the combination of basic sites and to the increase in active phase dispersion, respectively. However, it was observed that supporting a basic oxide on acidic support may decrease the catalytic activity. Anderson et al. [131] studied the role of $\mathrm{BaO}$ dispersion supported by alumina for the transesterification of cotton oil and groundnut oil $\left(65^{\circ} \mathrm{C}\right.$ and methanol/oil ratio 6:1). This group reported that, by increasing the amount of $\mathrm{BaO}$ in the catalyst, dispersion decreases since the catalyst activity depends on the oil used. Nevertheless, even though increasing the active phase decreases dispersion and, apparently, also the number of basic sites, the most active catalyst was $10 \mathrm{wt} . \% \mathrm{BaO}$ in both oils. Tonetto et al. [132] impregnated $\mathrm{K}, \mathrm{Na}$, and $\mathrm{Ba}$ on alumina ( $8 \mathrm{wt} . \%$ ) for the transesterification of soy oil (methanol/oil ratio 32:1, $1 \mathrm{wt} . \%, 120{ }^{\circ} \mathrm{C}, 6 \mathrm{~h}$ ). It was found that these materials had activity in the following order: $\mathrm{K} / \mathrm{Al}_{2} \mathrm{O}_{3}>\mathrm{Na} / \mathrm{Al}_{2} \mathrm{O}_{3}>\mathrm{Ca} / \mathrm{Al}_{2} \mathrm{O}_{3}>\mathrm{Ba} / \mathrm{Al}_{2} \mathrm{O}_{3}$. These two studies indicated that $\mathrm{BaO}$ is more effective as a mass catalyst than as a supported catalyst since highly dispersed molecules do not provide enough activity.

Mierczysnki et al. [130] proposed to support alkaline earth metal oxides (10 wt.\%) on $\mathrm{Sr}-\mathrm{Al}_{2} \mathrm{O}_{3}$ mixed oxide support for the transesterification of rapeseed oil in supercritical conditions $\left(350{ }^{\circ} \mathrm{C}\right.$ and $400^{\circ} \mathrm{C}$, with a methanol/oil ratio 25:1). It was determined that the highest FAME yield is attained at 400 and $350{ }^{\circ} \mathrm{C}$ for the rest, and the reactivity order was $\mathrm{Sr} / \mathrm{Sr}-\mathrm{Al}_{2} \mathrm{O}_{3}>\mathrm{Ca} / \mathrm{Sr}-\mathrm{Al}_{2} \mathrm{O}_{3}>\mathrm{Ba} / \mathrm{Sr}-\mathrm{Al}_{2} \mathrm{O}_{3}>\mathrm{Mg} / \mathrm{Sr}-\mathrm{Al}_{2} \mathrm{O}_{3}>\mathrm{Sr}-\mathrm{Al}_{2} \mathrm{O}_{3}$. This result was attributed to a higher degree of crystallinity of the catalyst that carried $\mathrm{SrO}$ as the active phase. Moreover, it was observed that $\mathrm{Sr} / \mathrm{Sr}-\mathrm{Al}_{2} \mathrm{O}_{3}$ was the least alkaline catalyst and, thus, its activity highly depends on the crystalline structure formed as $\mathrm{SrCO}_{3}$ or $\mathrm{Sr}_{12} \mathrm{Al}_{14} \mathrm{O}_{33}$. What is more, it was reported that $\mathrm{Mg} / \mathrm{Sr}-\mathrm{Al}_{2} \mathrm{O}_{3}$ leached strontium but not aluminum. $\mathrm{Ca} / \mathrm{Sr}-\mathrm{Al}_{2} \mathrm{O}_{3}$ catalyst did no leach strontium to the formed biodiesel support, but it leached aluminum. In contrast, $\mathrm{Sr} / \mathrm{Sr}-\mathrm{Al}_{2} \mathrm{O}_{3}$ leached both elements in the final product. Despite this, it was considered a stable catalyst since it leached less strontium and aluminum at $400{ }^{\circ} \mathrm{C}$ than $\mathrm{Sr}-\mathrm{Al}_{2} \mathrm{O}_{3}$ and $\mathrm{Ba} / \mathrm{Sr}-\mathrm{A}_{12} \mathrm{O}_{3}$. To optimize the $\mathrm{SrO} / \mathrm{Al}_{2} \mathrm{O}_{3}$ system to obtain biodiesel from palm oil, Mootabadi et al. used the central composite method with time, catalyst loading, alcohol/oil ration, and ultrasonic amplitude as variables $[133,134]$. Their model indicated that the alcohol/oil ratio and the amplitude of the ultrasonic processor are related. Furthermore, it was observed that increasing the amplitude can decrease the yield as it occurs with the methanol/oil ratio. The above attributed to an excessive amount of methanol, which can overly dilute the oil. Also, sonic stirring reduces the required amount of methanol. Therefore, it was concluded that the optimal conditions are obtained with a 
methanol/oil ratio of 9:2, $1.6 \mathrm{wt} . \%$ catalyst, a $69.7 \%$ amplitude during $30.2 \mathrm{~min}$ to attain an $80.2 \%$ yield.

Tangy et al. [135] synthesized a SrO catalyst (41.3 wt.\%) supported by $\mathrm{SiO}_{2}$ spherical beads to test it in the transesterification of used oil heated in a microwave, for it has been shown to be an efficient method since the radiation reaches the reagents directly. In the catalyst synthesis, microwave radiation was also used to rapidly transform $\mathrm{Sr}\left(\mathrm{NO}_{3}\right)_{2}$ in $\mathrm{SrCO}_{3}$ so it can efficiently adhere to the silica beads; and, after calcination at $900{ }^{\circ} \mathrm{C}, \mathrm{SrO}$ crystals of $55 \mathrm{~nm}$ were formed. The reaction results demonstrated that a $99.4 \%$ FAME yield was attained in $10 \mathrm{~s}$, attributed to the well-dispersed metallic oxide nanoparticles in the support. Additionally, the system proved to be efficient for up to 10 cycles. However, the system has a limitation in industrial scaling, which represents a technological challenge.

$\mathrm{MgO}$ modified with $\mathrm{SrO}$ was studied recently on the transesterification of wasted oil by Shahbazi et al. [136]. In this work, the authors proposed the co-precipitation synthesis method at different $\mathrm{SrO} / \mathrm{MgO}$ molar ratios. The wet impregnation synthesis method (20\% of $\mathrm{SrO}$ ) and pure $\mathrm{SrO}$ and $\mathrm{MgO}$ were used as a reference. The catalysts were calcined at $850{ }^{\circ} \mathrm{C}$ for $5 \mathrm{~h}$. The co-precipitated catalysts were more active than the wet impregnated and pure references. Also, the optimal $\mathrm{SrO} / \mathrm{MgO}$ ratio was found to be 3:7. This material presented super basic sites on its surface, as it was showed by Hammett indicators and $\mathrm{CO}_{2}$-TPD results; therefore, it showed the higher biodiesel yields. All reactions were carried out with $0.1 \mathrm{~g}$ of catalyst, methanol/oil ratio of 9:1 at $60{ }^{\circ} \mathrm{C}$ for $2 \mathrm{~h}$. The results are presented in Table 5 .

Table 5. Comparison of the basic strength, approximate basic sites and biodiesel yields of the co-precipitated $\mathrm{SrO} / \mathrm{MgO}$, wet impregnated $\mathrm{SrO} / \mathrm{MgO}$ and pure $\mathrm{SrO}, \mathrm{MgO}$ catalysts. [136].

\begin{tabular}{cccc}
\hline Catalyst & Basic Strength & $\begin{array}{c}\text { Approximate Total Basic } \\
\text { Sites (mmol CO }\end{array}$ & Biodiesel Yield (\%) \\
\hline Co-precipitated SrO/MgO & $27 \geq \mathrm{H}_{-} \geq 22$ & 71 & 79 \\
Wet Impregnated SrO/MgO & $18 \geq \mathrm{H}_{-} \geq 15$ & 34 & 52 \\
Strontium oxide & $15 \geq \mathrm{H}_{-} \geq 9$ & 37 & 48 \\
Magnesium oxide & $9 \geq \mathrm{H}^{-1}$ & 10 & 4 \\
\hline
\end{tabular}

The basic sites were classified as moderate, strong, and super basic. The moderate basic sites were attributed to $\mathrm{Mg}^{2+}-\mathrm{O}^{2-}$ species, the strong to $\mathrm{Sr}^{2+}-\mathrm{O}^{2-}$ and the super basic to isolated $\mathrm{O}^{2-}$ sites. The co-precipitated catalyst showed to be $20 \%$ more active than the impregnated catalyst. Also, they found that if the calcination temperature of the coprecipitated catalysts is increased to $950{ }^{\circ} \mathrm{C}$ or $1050{ }^{\circ} \mathrm{C}$, the catalytic activity would decrease. This was attributed to the incomplete decomposition of the carbonate and hydroxide compounds that provide the active sites and remain at $850{ }^{\circ} \mathrm{C}$. At higher temperatures, the complete oxide species formed would agglomerate and lose crystalline phases and active sites. This material reached a biodiesel yield of $79.4 \%$ using $0.1 \mathrm{~g}$ of catalysts with a methanol/oil molar ratio of 9:1 at $60{ }^{\circ} \mathrm{C}$ for $2 \mathrm{~h}$. However, by a Box-Behnken response surface model, the reaction conditions were optimized to a biodiesel yield of $88 \%$ using $0.1 \mathrm{~g}$ of catalyst, methanol/oil ratio of 7.7 at $50.16{ }^{\circ} \mathrm{C}$ for $1.37 \mathrm{~h}$. Furthermore, the coprecipitated catalysts demonstrated that they could be reusable for four cycles keeping a biodiesel yield higher than $80 \%$.

The strontium oxide three metallic systems combined with calcium oxide and aluminum oxide were studied recently by Zhang et al. in the transesterification of palm oil with methanol under microwave irradiation [137]. The optimal catalytic conditions were found to be at a catalyst concentration of $7.5 \mathrm{wt} . \%$ at $65{ }^{\circ} \mathrm{C}$ with a methanol/oil ratio of 15:1 for $3 \mathrm{~h}$. The maximum FAME yield was $95.9 \%$ and was achieved by the SrO to $\mathrm{CaO}$ mass ratio of 0.4 in the $\mathrm{SrO}-\mathrm{CaO}-\mathrm{Al}_{2} \mathrm{O}_{3}$ catalyst. Likewise, the biodiesel yields only decreased to $92 \%$ in five cycles. At higher $\mathrm{SrO}$ to $\mathrm{CaO}$ mass ratios, there is no difference in the catalytic activity. These improvements in the catalytic performance were attributed to the $\mathrm{Ca}_{12} \mathrm{Al}_{14} \mathrm{O}_{33}$ and $\mathrm{Ca}_{0.2} \mathrm{Sr}_{0.8} \mathrm{O}$ phases found by XRD, FTIRS, and XPS analysis. The 
strontium also decorates the surface of the catalysts, increasing the effective negative charge of the superficial oxygen, i.e., the oxygen enhances its electron-donating properties. Consequently, the basic character was increased. Furthermore, the presence of the strontium also modifies the interactions between the calcium and aluminum cations, which results in the stability of the $\mathrm{Ca}^{2+}$ species and reducing their leach. Hence, the combination of $\mathrm{CaO}$ with $\mathrm{Al}_{2} \mathrm{O}_{3}$ brings stability to the support, and it can be improved by $\mathrm{SrO}$ in the final catalyst.

\section{Conclusions}

Catalysts made from alkaline earth oxides seem to be a viable option for transesterification reactions since they offer advantages like easy separation and recovery, reduced corrosion, and environmental acceptance. However, there still are disadvantages that must be minimized or eliminated to increase their yield.

At present, biodiesel development from vegetable oils has mainly focused on three aspects: the development of new catalysts, the modulation of reaction conditions, and the development of optimization models. Firstly, one of the main objectives is to increase the material's basicity, and different ways to achieve it have been proposed. At this point, an important catalytic variable is the crystal size, which relates to the catalyst's basic strength and depends on the thermal calcination treatment. Moreover, this treatment affects the dispersion and, in oxide mixtures, the morphology. Another important factor is the catalyst's tendency to deactivate with water and atmospheric $\mathrm{CO}_{2}$ since both have an affinity for basic sites, and it is hard to avoid. As a solution to this, calcination in an inert atmosphere has been proposed. Nevertheless, if this technology is applied in rural areas, an inert calcination system might increase biofuel costs. Therefore, to solve this problem, it was proposed to mix alkaline earth oxides with other oxides, such as alkaline metals, to increment their basicity or disperse it with support so that active sites are more available and resistant to environmental factors. Likewise, eggshells, bones, and natural minerals have been proposed as viable alternatives to facilitate access to catalysts since they are more resistant to metallic oxide factors. In the same way, it is important to know if the catalyst can be reused and how many cycles it is capable to keep its activity because almost all these materials lixiviate in the presence of methanol. To achieve all of this, it is necessary to design a highly stable catalyst to avoid lixiviation; with high basicity; it won't be contaminated with the presence of water or atmospheric $\mathrm{CO}_{2}$; inexpensive, reusable, and not toxic. Based on the aforementioned, different studies have proposed the use of other metallic oxides, for example, $\mathrm{ZnO}, \mathrm{TiO}_{2}, \mathrm{ZrO}_{2}, \mathrm{La}_{2} \mathrm{O}_{3}, \mathrm{SiO}_{2}, \mathrm{CeO}_{2}$, basic mixed oxides, among others. The analysis of this type of materials is available in the literature, and their study for further application has increased, particularly for $\mathrm{La}_{2} \mathrm{O}_{3}$, which seems to be the most promising.

The reaction conditions have a wide operating range since it is possible to perform this type of reactions in atmospheric conditions and at temperatures below the used alcohol's boiling point or in supercritical conditions. Some works have focused on supercritical conditions; however, these increase the costs of operation. In addition, the typical conditions for transesterification are more economical, but yields are lower than the supercritical ones, which notably improve the reaction yield. Furthermore, the use of ultrasonic stirring has been proposed since it minimizes mass transfer problems by improving the mixing of alcohol and oil. Consequently, the optimization of such conditions is necessary. Optimization studies have used different experimental design methods to find the relation between variables and improved efficiency conditions, as well as to propose models that predict the systems' behavior. These studies have concluded that the main variables are the alcohol/oil ratio, temperature, reaction time, catalyst loading, and revolutions or flow rate. In more particular cases, the ultrasonic frequency has been studied along with microwave power and pressure. Some more specialized studies have focused on creating models to improve reactors based on kinetic models and simulations involving transport phenomena. Finally, first-generation biofuels are a viable option to decrease the use of fossil fuels. Still, it requires further studying for a correct implementation from small plants that can be 
relocated in rural areas to industrial levels. The different economic, technological, and environmental challenges could be addressed by studying, assessing, and implementing different alternatives according to the necessities.

Author Contributions: Conceptualization, design and writing—original draft preparation; J.A.T.-P. and J.A.R.; Data curation and writing-original draft preparation; V.A.S.-T., G.C.-E. and O.A.L.-R.; investigation; O.U.V.-M. and A.T.-L.; funding acquisition; J.A.R. and C.E.S.-V. All authors have read and agreed to the published version of the manuscript.

Funding: This research was funded by CONACYT-México for the projects 216 and 965 of CátedrasCONACYT. Instituto Politécnico Nacional Projects SIP-20210204, SIP-20201116 and SIP-20201629.

Acknowledgments: Authors are grateful to Christian Márquez, Marcela Daumas Posada, and Tania Valadez Lugo for the translation and edition to English.

Conflicts of Interest: The authors declare no conflict of interest.

\section{References}

1. Al Rashdan, M.; Al Zubi, M.; Al Okour, M. Effect of Using New Technology Vehicles on the World's Environment and Petroleum Resources. J. Ecol. Eng. 2019, 20, 16-24. [CrossRef]

2. Oil Prices. Available online: www.oilprice.com (accessed on 19 April 2020).

3. Tans, P.; Keeling, R. Trends in Atmospheric Carbon Dioxide. Available online: http:/ /www.esrl.noaa.gov/gmd/ccgg/trends / mlo.html\#mlo_full (accessed on 7 January 2012).

4. Ballesteros, M.; Manzanares, P. Liquid Biofuels. In The Role of Bioenergy in the Bioeconomy; Elago, C., Caldés, N., Lechón, Y., Eds.; Academic Press: Amsterdam, The Netherlands, 2019; pp. 113-144.

5. Oh, Y.-K.; Hwang, K.-R.; Kim, C.; Kim, J.R.; Lee, J.-S. Recent developments and key barriers to advanced biofuels: A short review. Bioresour. Technol. 2018, 257, 320-333. [CrossRef] [PubMed]

6. IEA. Global Energy \& CO2 Status Report. Available online: https://www.iea.org/geco/emissions/ (accessed on 19 April 2020).

7. Höök, M.; Tang, X. Depletion of fossil fuels and anthropogenic climate change-A review. Energy Policy 2013, 52, 797-809. [CrossRef]

8. Manaf, I.S.A.; Embong, N.H.; Khazaai, S.N.M.; Rahim, M.H.A.; Yusoff, M.M.; Lee, K.T.; Maniam, G.P. A review for key challenges of the development of biodiesel industry. Energy Convers. Manag. 2019, 185, 508-517. [CrossRef]

9. Paris Agreement, U.N. The Paris Agreement. Available online: https://unfccc.int/process-and-meetings/the-paris-agreement/ the-paris-agreement (accessed on 19 April 2019).

10. Cespi, D.; Esposito, I.; Cucciniello, R.; Anastas, P.T. Beyond the beaker: Benign by design society. Curr. Res. Green Sustain. Chem. 2020, 3, 100028. [CrossRef]

11. Sunde, K.; Brekke, A.; Solberg, B. Environmental impacts and costs of woody Biomass-to-Liquid (BTL) production and use-A review. For. Policy Econ. 2011, 13, 591-602. [CrossRef]

12. Chanthawong, A.; Dhakal, S. Liquid Biofuels Development in Southeast Asian Countries: An Analysis of Market, Policies and Challenges. Waste Biomass-Valorization 2015, 7, 157-173. [CrossRef]

13. Efthymiopoulos, I.; Hellier, P.; Ladommatos, N.; Kay, A.; Mills-Lamptey, B. Effect of Solvent Extraction Parameters on the Recovery of Oil From Spent Coffee Grounds for Biofuel Production. Waste Biomass-Valorization 2019, 10, 253-264. [CrossRef]

14. Correa, D.F.; Beyer, H.L.; Possingham, H.P.; Thomas-Hall, S.R.; Schenk, P.M. Biodiversity impacts of bioenergy production: Microalgae vs. first generation biofuels. Renew. Sustain. Energy Rev. 2017, 74, 1131-1146. [CrossRef]

15. Alalwan, H.A.; Alminshid, A.H.; Aljaafari, H.A. Promising evolution of biofuel generations. Subject review. Renew. Energy Focus 2019, 28, 127-139. [CrossRef]

16. Hill, J.; Nelson, E.; Tilman, D.; Polasky, S.; Tiffany, D.G. Environmental, economic, and energetic costs and benefits of biodiesel and ethanol biofuels. Proc. Natl. Acad. Sci. USA 2006, 103, 11206-11210. [CrossRef]

17. Van Gerpen, J. Biodiesel processing and production. Fuel Process. Technol. 2005, 86, 1097-1107. [CrossRef]

18. Parada, M.P.; Osseweijer, P.; Duque, J.A.P. Sustainable biorefineries, an analysis of practices for incorporating sustainability in biorefinery design. Ind. Crop. Prod. 2017, 106, 105-123. [CrossRef]

19. Abdullah, B.; Muhammad, S.A.F.S.; Shokravi, Z.; Ismail, S.; Kassim, K.A.; Mahmood, A.N.; Aziz, M.A. Fourth generation biofuel: A review on risks and mitigation strategies. Renew. Sustain. Energy Rev. 2019, 107, 37-50. [CrossRef]

20. Amini, Z.; Ilham, Z.; Ong, H.C.; Mazaheri, H.; Chen, W.-H. State of the art and prospective of lipase-catalyzed transesterification reaction for biodiesel production. Energy Convers. Manag. 2017, 141, 339-353. [CrossRef]

21. Ngoie, W.I.; Oyekola, O.O.; Ikhu-Omoregbe, D.; Welz, P.J. Valorisation of Edible Oil Wastewater Sludge: Bioethanol and Biodiesel Production. Waste Biomass-Valorization 2019, 11, 2431-2440. [CrossRef]

22. Tajuddin, N.; Lee, A.; Wilson, K. Production of biodiesel via catalytic upgrading and refining of sustainable oleagineous feedstocks. In Handbook of Biodiesel Production, 2nd ed.; Luque, R., Lin, C.S.K., Wilson, K., Clark, J., Eds.; Woodhead Publishing Series in Energy: Cambridge, UK, 2016; pp. 121-164. 
23. García, I. Feedstocks and challenges to biofuel development. In Handbook of Biodiesel Production, 2nd ed.; Luque, R., Lin, C.S.K., Wilson, K., Clark, J., Eds.; Woodhead Publishing Series in Energy: Cambridge, UK, 2016; pp. 85-118.

24. Le Anh, T.; Reksowardojo, I.; Wattanavichien, K. Utilization of biofuels in diesel engines. In Handbook of Biodiesel Production, 1st ed.; Luque, R., Campelo, J., Clark, J., Eds.; Woodhead Publishing: Cambridge, UK, 2011; pp. 611-646.

25. Marchetti, J.; Miguel, V.; Errazu, A. Possible methods for biodiesel production. Renew. Sustain. Energy Rev. 2007, 11, 1300-1311. [CrossRef]

26. Bateni, H.; Bateni, F.; Karimi, K. Effects of Oil Extraction on Ethanol and Biogas Production from Eruca sativa Seed Cake. Waste Biomass-Valorization 2016, 8, 1897-1905. [CrossRef]

27. Demirbas, M.F. Biofuels from algae for sustainable development. Appl. Energy 2011, 88, 3473-3480. [CrossRef]

28. Ajanovic, A. Biofuels versus food production: Does biofuels production increase food prices? Energy 2011, 36, 2070-2076. [CrossRef]

29. Garlapati, V.K.; Tewari, S.; Ganguly, R. Life Cycle Assessment of First-, Second-Generation, and Microalgae Biofuels. In Advances in Feedstock Conversion Technologies for Alternative Fuels and Bioproducts, 1st ed.; Hosseini, M., Ed.; Woodhead Publishing Series in Energy: Cambridge, UK, 2019; pp. 355-371.

30. Demirbas, A. Biodiesel production from vegetable oils via catalytic and non-catalytic supercritical methanol transesterification methods. Prog. Energy Combust. Sci. 2005, 31, 466-487. [CrossRef]

31. Borges, M.; Díaz, L. Recent developments on heterogeneous catalysts for biodiesel production by oil esterification and transesterification reactions: A review. Renew. Sustain. Energy Rev. 2012, 16, 2839-2849. [CrossRef]

32. Khan, T.M.Y.; Atabani, A.E.; Irfananjumbadruddin, I.; Badarudin, A.; Khayoon, M.S.; Triwahyono, S. Recent scenario and technologies to utilize non-edible oils for biodiesel production. Renew. Sustain. Energy Rev. 2014, 37, 840-851. [CrossRef]

33. Joshi, G.; Pandey, J.K.; Rana, S.; Rawat, D.S. Challenges and opportunities for the application of biofuel. Renew. Sustain. Energy Rev. 2017, 79, 850-866. [CrossRef]

34. Atabani, A.; Silitonga, A.; Badruddin, I.A.; Mahlia, T.; Masjuki, H.; Mekhilef, S. A comprehensive review on biodiesel as an alternative energy resource and its characteristics. Renew. Sustain. Energy Rev. 2012, 16, 2070-2093. [CrossRef]

35. Marwaha, A.; Dhir, A.; Mahla, S.K.; Mohapatra, S.K. An overview of solid base heterogeneous catalysts for biodiesel production. Catal. Rev. 2018, 60, 594-628. [CrossRef]

36. Tariq, M.; Ali, S.; Khalid, N. Activity of homogeneous and heterogeneous catalysts, spectroscopic and chromatographic characterization of biodiesel: A review. Renew. Sustain. Energy Rev. 2012, 16, 6303-6316. [CrossRef]

37. Demirbas, A. Production of biodiesel fuels from linseed oil using methanol and ethanol in non-catalytic SCF conditions. BiomassBioenergy 2009, 33, 113-118. [CrossRef]

38. Darnoko, D.; Cheryan, M. Kinetics of palm oil transesterification in a batch reactor. J. Am. Oil Chem. Soc. 2000, 77, 1263-1267. [CrossRef]

39. Portha, J.-F.; Allain, F.H.T.; Coupard, V.; Dandeu, A.; Girot, E.; Schaer, E.; Falk, L. Simulation and kinetic study of transesterification of triolein to biodiesel using modular reactors. Chem. Eng. J. 2012, 207-208, 285-298. [CrossRef]

40. Dehkhoda, A.M.; West, A.H.; Ellis, N. Biochar based solid acid catalyst for biodiesel production. Appl. Catal. A Gen. 2010, 382, 197-204. [CrossRef]

41. Di Serio, M.; Tesser, R.; Pengmei, L.; Santacesaria, E. Heterogeneous Catalysts for Biodiesel Production. Energy Fuels 2008, 22, 207-217. [CrossRef]

42. Konwar, L.J.; Boro, J.; Deka, D. Review on latest developments in biodiesel production using carbon-based catalysts. Renew. Sustain. Energy Rev. 2014, 29, 546-564. [CrossRef]

43. Kulkarni, M.G.; Gopinath, R.; Meher, L.C.; Dalai, A.K. Solid acid catalyzed biodiesel production by simultaneous esterification and transesterification. Green Chem. 2006, 8, 1056-1062. [CrossRef]

44. Gan, S.; Ng, H.K.; Ooi, C.W.; Motala, N.O.; Ismail, M.A.F. Ferric sulphate catalysed esterification of free fatty acids in waste cooking oil. Bioresour. Technol. 2010, 101, 7338-7343. [CrossRef]

45. Meher, L.; Sagar, D.V.; Naik, S. Technical aspects of biodiesel production by transesterification-A review. Renew. Sustain. Energy Rev. 2006, 10, 248-268. [CrossRef]

46. Demirbaş, A. Biodiesel fuels from vegetable oils via catalytic and non-catalytic supercritical alcohol transesterifications and other methods: A survey. Energy Convers. Manag. 2003, 44, 2093-2109. [CrossRef]

47. Zabeti, M.; Daud, W.M.A.W.; Aroua, M.K. Activity of solid catalysts for biodiesel production: A review. Fuel Process. Technol. 2009, 90, 770-777. [CrossRef]

48. Furuta, S.; Matsuhashi, H.; Arata, K. Biodiesel fuel production with solid superacid catalysis in fixed bed reactor under atmospheric pressure. Catal. Commun. 2004, 5, 721-723. [CrossRef]

49. Van Kasteren, J.H.; Nisworo, A. A process model to estimate the cost of industrial scale biodiesel production from waste cooking oil by supercritical transesterification. Resour. Conserv. Recycl. 2007, 50, 442-458. [CrossRef]

50. Leung, D.Y.; Wu, X.; Leung, M. A review on biodiesel production using catalyzed transesterification. Appl. Energy 2010, 87, 1083-1095. [CrossRef]

51. Helwani, Z.; Othman, M.; Aziz, N.; Kim, J.; Fernando, W. Solid heterogeneous catalysts for transesterification of triglycerides with methanol: A review. Appl. Catal. A Gen. 2009, 363, 1-10. [CrossRef] 
52. Ezebor, F.; Khairuddean, M.; Abdullah, A.Z.; Boey, P.L. Oil palm trunk and sugarcane bagasse derived solid acid catalysts for rapid esterification of fatty acids and moisture-assisted transesterification of oils under pseudo-infinite methanol. Bioresour. Technol. 2014, 157, 254-262. [CrossRef] [PubMed]

53. Takagaki, A.; Toda, M.; Okamura, M.; Kondo, J.N.; Hayashi, S.; Domen, K.; Hara, M. Esterification of higher fatty acids by a novel strong solid acid. Catal. Today 2006, 116, 157-161. [CrossRef]

54. Su, F.; Guo, Y. Advancements in solid acid catalysts for biodiesel production. Green Chem. 2014, 16, 2934-2957. [CrossRef]

55. Tavizón-Pozos, J.A.; Ibarra, I.S.; Guevara-Lara, A.; Galán-Vidal, C.A. Application of Design of Experiments in Biofuel Production: A Review. In Design of Experiments for Chemical, Pharmaceutical, Food, and Industrial Applications; IGI Global: Hershey, PA, USA, 2020; pp. 77-103.

56. Veljković, V.B.; Veličković, A.V.; Avramović, J.M.; Stamenković, O.S. Modeling of biodiesel production: Performance comparison of Box-Behnken, face central composite and full factorial design. Chin. J. Chem. Eng. 2019, 27, 1690-1698. [CrossRef]

57. Karmakar, B.; Dhawane, S.H.; Halder, G. Optimization of biodiesel production from castor oil by Taguchi design. J. Environ. Chem. Eng. 2018, 6, 2684-2695. [CrossRef]

58. Dodo, R.; Ause, T.; Dauda, E.; Shehu, U.; Popoola, A. Multi-response optimization of transesterification parameters of mahogany seed oil using grey relational analysis in Taguchi method for quenching application. Heliyon 2019, 5, e02167. [CrossRef]

59. Silitonga, A.; Shamsuddin, A.; Mahlia, T.; Milano, J.; Kusumo, F.; Siswantoro, J.; Dharma, S.; Sebayang, A.; Masjuki, H.; Ong, H.C. Biodiesel synthesis from Ceiba pentandra oil by microwave irradiation-assisted transesterification: ELM modeling and optimization. Renew. Energy 2020, 146, 1278-1291. [CrossRef]

60. Kumar, S.A.; Sakthinathan, G.; Vignesh, R.; Banu, J.R.; Al-Muhtaseb, A.H. Optimized transesterification reaction for efficient biodiesel production using Indian oil sardine fish as feedstock. Fuel 2019, 253, 921-929. [CrossRef]

61. Verma, P.; Sharma, M. Comparative analysis of effect of methanol and ethanol on Karanja biodiesel production and its optimisation. Fuel 2016, 180, 164-174. [CrossRef]

62. Vinayaka, A.S.; Mahanty, B.; Rene, E.R.; Behera, S.K. Biodiesel production by transesterification of a mixture of pongamia and neem oils. Biofuels 2018, 1-9. [CrossRef]

63. Endut, A.; Abdullah, S.H.Y.S.; Hanapi, N.H.M.; Hamid, S.H.A.; Lananan, F.; Kamarudin, M.K.A.; Umar, R.; Juahir, H.; Khatoon, $\mathrm{H}$. Optimization of biodiesel production by solid acid catalyst derived from coconut shell via response surface methodology. Int. Biodeterior. Biodegrad. 2017, 124, 250-257. [CrossRef]

64. Abdullah, S.H.Y.S.; Hanapi, N.H.M.; Azid, A.; Umar, R.; Juahir, H.; Khatoon, H.; Endut, A. A review of biomass-derived heterogeneous catalyst for a sustainable biodiesel production. Renew. Sustain. Energy Rev. 2017, 70, 1040-1051. [CrossRef]

65. Kouzu, M.; Hidaka, J.-S. Transesterification of vegetable oil into biodiesel catalyzed by CaO: A review. Fuel 2012, 93, 1-12. [CrossRef]

66. Dossin, T.F.; Reyniers, M.-F.; Berger, R.J.; Marin, G.B. Simulation of heterogeneously MgO-catalyzed transesterification for fine-chemical and biodiesel industrial production. Appl. Catal. B Environ. 2006, 67, 136-148. [CrossRef]

67. Li, H.; Niu, S.; Lu, C.; Li, J. Calcium oxide functionalized with strontium as heterogeneous transesterification catalyst for biodiesel production. Fuel 2016, 176, 63-71. [CrossRef]

68. D'Cruz, A.; Kulkarni, M.G.; Meher, L.C.; Dalai, A.K. Synthesis of Biodiesel from Canola Oil Using Heterogeneous Base Catalyst. J. Am. Oil Chem. Soc. 2007, 84, 937-943. [CrossRef]

69. Chouhan, A.S.; Sarma, A. Modern heterogeneous catalysts for biodiesel production: A comprehensive review. Renew. Sustain. Energy Rev. 2011, 15, 4378-4399. [CrossRef]

70. Ling, J.S.J.; Tan, Y.H.; Mubarak, N.M.; Kansedo, J.; Saptoro, A.; Nolasco-Hipolito, C. A review of heterogeneous calcium oxide based catalyst from waste for biodiesel synthesis. SN Appl. Sci. 2019, 1, 810. [CrossRef]

71. Yan, S.; Lu, H.; Liang, B. Supported CaO Catalysts Used in the Transesterification of Rapeseed Oil for the Purpose of Biodiesel Production. Energy Fuels 2008, 22, 646-651. [CrossRef]

72. Chen, C.-L.; Huang, C.-C.; Tran, D.-T.; Chang, J.-S. Biodiesel synthesis via heterogeneous catalysis using modified strontium oxides as the catalysts. Bioresour. Technol. 2012, 113, 8-13. [CrossRef]

73. Endalew, A.K.; Kiros, Y.; Zanzi, R. Inorganic heterogeneous catalysts for biodiesel production from vegetable oils. BiomassBioenergy 2011, 35, 3787-3809. [CrossRef]

74. Watkins, R.S.; Lee, A.; Wilson, K. Li/CaO catalysed tri-glyceride transesterification for biodiesel applications. Green Chem. 2004, 6, 335-340. [CrossRef]

75. Hattori, H.; Shima, M.; Kabashima, H. Alcoholysis of ester and epoxide catalyzed by solid bases. In Studies in Surface Science and Catalysis; Corma, A., Melo, F.V., Mendioroz, S., Fierro, J.L.G., Eds.; Elsevier BV: Granada, Spain, 2000; Volume 130, pp. 3507-3512.

76. Ruppert, A.M.; Meeldijk, J.D.; Kuipers, B.W.M.; Erné, B.H.; Weckhuysen, B.M. Glycerol Etherification over Highly Active CaO-Based Materials: New Mechanistic Aspects and Related Colloidal Particle Formation. Chem. Eur. J. 2008, 14, $2016-2024$. [CrossRef]

77. Patil, P.D.; Deng, S. Transesterification of Camelina Sativa Oil Using Heterogeneous Metal Oxide Catalysts. Energy Fuels 2009, 23, 4619-4624. [CrossRef]

78. Gryglewicz, S. Rapeseed oil methyl esters preparation using heterogeneous catalysts. Bioresour. Technol. 1999, 70, $249-253$. [CrossRef]

79. Hattori, H. Heterogeneous Basic Catalysis. Chem. Rev. 1995, 95, 537-558. [CrossRef] 
80. Montero, J.M.; Gai, P.; Wilson, K.; Lee, A. Structure-sensitive biodiesel synthesis over MgO nanocrystals. Green Chem. 2009, 11, 265-268. [CrossRef]

81. Jeon, H.; Kim, D.J.; Kim, S.J.; Kim, J.H. Synthesis of mesoporous MgO catalyst templated by a PDMS-PEO comb-like copolymer for biodiesel production. Fuel Process. Technol. 2013, 116, 325-331. [CrossRef]

82. Dossin, T.; Reyniers, M.; Marin, G. Kinetics of heterogeneously MgO-catalyzed transesterification. Appl. Catal. B Environ. 2006, 62, 35-45. [CrossRef]

83. Demirbas, A. Biodiesel from Vegetable Oils with MgO Catalytic Transesterification in Supercritical Methanol. Energy Sources Part A Recover. Util. Environ. Eff. 2008, 30, 1645-1651. [CrossRef]

84. Ilgen, O.; Akin, A.N. Transesterification of Canola Oil to Biodiesel Using MgO Loaded with KOH as a Heterogeneous Catalyst. Energy Fuels 2009, 23, 1786-1789. [CrossRef]

85. Hu, J.; Zhu, K.; Chen, L.; Kübel, C.; Richards, R.; Kuebel, C. MgO(111) Nanosheets with Unusual Surface Activity. J. Phys. Chem. C 2007, 111, 12038-12044. [CrossRef]

86. Klabunde, K.J.; Erickson, L.E.; Koper, O.; Richards, R.M. Review of Nanoscale Materials in Chemistry: Environmental Applications. In ACS Symposium Series; Erickson, L., Koodali, R., Richards, R.M., Eds.; American Chemical Society (ACS): Washington, DC, USA, 2010; Volume 1045, pp. 1-13.

87. Li, W.-C.; Lu, A.-H.; Weidenthaler, A.C.; Schüth, F. Hard-Templating Pathway to Create Mesoporous Magnesium Oxide. Chem. Mater. 2004, 16, 5676-5681. [CrossRef]

88. Richards, R.; Li, W.; Decker, S.; Davidson, C.; Koper, O.; Zaikovski, V.; Volodin, A.; Rieker, T.; Klabunde, K.J. Consolidation of Metal Oxide Nanocrystals. Reactive Pellets with Controllable Pore Structure That Represent a New Family of Porous, Inorganic Materials. J. Am. Chem. Soc. 2000, 122, 4921-4925. [CrossRef]

89. Verziu, M.; Cojocaru, B.; Hu, J.; Richards, R.; Ciuculescu, C.; Filip, P.I.; Pârvulescu, V.I. Sunflower and rapeseed oil transesterification to biodiesel over different nanocrystalline MgO catalysts. Green Chem. 2008, 10, 373-381. [CrossRef]

90. Rasouli, H.; Esmaeili, H. Characterization of MgO nanocatalyst to produce biodiesel from goat fat using transesterification process. 3 Biotech 2019, 9, 429. [CrossRef] [PubMed]

91. Amirthavalli, V.; Warrier, A.R. Production of biodiesel from waste cooking oil using MgO nanocatalyst. In Dae Solid State Physics Symposium 2018; Biswas, A., Veerendra, K., Eds.; AIP Publishing Conference Proceedings: Hisar, Haryana, India, 2019; Volume 2115. [CrossRef]

92. Sharma, Y.C.; Singh, B.; Korstad, J. Latest developments on application of heterogenous basic catalysts for an efficient and eco friendly synthesis of biodiesel: A review. Fuel 2011, 90, 1309-1324. [CrossRef]

93. Ngamcharussrivichai, C.; Nunthasanti, P.; Tanachai, S.; Bunyakiat, K. Biodiesel production through transesterification over natural calciums. Fuel Process. Technol. 2010, 91, 1409-1415. [CrossRef]

94. Zhang, C.-Y.; Shao, W.-L.; Zhou, W.-X.; Liu, Y.; Han, Y.-Y.; Zheng, Y.; Liu, Y.-J. Biodiesel Production by Esterification Reaction on $\mathrm{K}^{+}$Modified MgAl-Hydrotalcites Catalysts. Catalysts 2019, 9, 742. [CrossRef]

95. Jindapon, W.; Ngamcharussrivichai, C. Heterogeneously catalyzed transesterification of palm oil with methanol to produce biodiesel over calcined dolomite: The role of magnesium oxide. Energy Convers. Manag. 2018, 171, 1311-1321. [CrossRef]

96. Rabie, A.M.; Shaban, M.; Abukhadra, M.R.; Hosny, R.; Ahmed, S.A.; Negm, N.A. Diatomite supported by CaO/MgO nanocomposite as heterogeneous catalyst for biodiesel production from waste cooking oil. J. Mol. Liq. 2019, 279, 224-231. [CrossRef]

97. Modiba, E.; Enweremadu, C.; Rutto, H. Production of biodiesel from waste vegetable oil using impregnated diatomite as heterogeneous catalyst. Chin. J. Chem. Eng. 2015, 23, 281-289. [CrossRef]

98. Liu, X.; He, H.; Wang, Y.; Zhu, S.; Piao, X. Transesterification of soybean oil to biodiesel using CaO as a solid base catalyst. Fuel 2008, 87, 216-221. [CrossRef]

99. Kouzu, M.; Kasuno, T.; Tajika, M.; Sugimoto, Y.; Yamanaka, S.; Hidaka, J. Calcium oxide as a solid base catalyst for transesterification of soybean oil and its application to biodiesel production. Fuel 2008, 87, 2798-2806. [CrossRef]

100. Iizuka, T.; Hattori, H.; Ohno, Y.; Sohma, J.; Tanabe, K. Basic sites and reducing sites of calcium oxide and their catalytic activities. J. Catal. 1971, 22, 130-139. [CrossRef]

101. Kouzu, M.; Kasuno, T.; Tajika, M.; Yamanaka, S.; Hidaka, J. Active phase of calcium oxide used as solid base catalyst for transesterification of soybean oil with refluxing methanol. Appl. Catal. A Gen. 2008, 334, 357-365. [CrossRef]

102. Kouzu, M.; Hidaka, J.-S.; Wakabayashi, K.; Tsunomori, M. Solid base catalysis of calcium glyceroxide for a reaction to convert vegetable oil into its methyl esters. Appl. Catal. A Gen. 2010, 390, 11-18. [CrossRef]

103. Meher, L.C.; Kulkarni, M.G.; Dalai, A.K.; Naik, S.N. Transesterification of karanja(Pongamia pinnata) oil by solid basic catalysts. Eur. J. Lipid Sci. Technol. 2006, 108, 389-397. [CrossRef]

104. Kaur, M.; Ali, A. Lithium ion impregnated calcium oxide as nano catalyst for the biodiesel production from karanja and jatropha oils. Renew. Energy 2011, 36, 2866-2871. [CrossRef]

105. Wen, L.; Wang, Y.; Lu, D.; Hu, S.; Han, H. Preparation of KF/CaO nanocatalyst and its application in biodiesel production from Chinese tallow seed oil. Fuel 2010, 89, 2267-2271. [CrossRef]

106. Kumar, D.; Ali, A. Nanocrystalline $\mathrm{K}-\mathrm{CaO}$ for the transesterification of a variety of feedstocks: Structure, kinetics and catalytic properties. Biomass-Bioenergy 2012, 46, 459-468. [CrossRef] 
107. Schaafsma, A.; Pakan, I.; Hofstede, G.J.H.; Muskiet, F.A.; Van Der Veer, E.; De Vries, P.J.F. Mineral, amino acid, and hormonal composition of chicken eggshell powder and the evaluation of its use in human nutrition. Poult. Sci. 2000, 79, 1833-1838. [CrossRef]

108. Boey, P.-L.; Maniam, G.P.; Hamid, S.A. Utilization of waste crab shell (Scylla serrata) as a catalyst in palm olein transesterification. J. Oleo Sci. 2009, 58, 499-502. [CrossRef]

109. Al-Zaini, E.O.; Olsen, J.; Nguyen, T.H.; Adesina, A. Transesterification of Waste Cooking Oil in Presence of Crushed Seashell as a Support for Solid Heterogeneous Catalyst. SAE Int. J. Fuels Lubr. 2011, 4, 139-157. [CrossRef]

110. Boro, J.; Konwar, L.J.; Deka, D. Transesterification of non edible feedstock with lithium incorporated egg shell derived CaO for biodiesel production. Fuel Process. Technol. 2014, 122, 72-78. [CrossRef]

111. Viriya-Empikul, N.; Krasae, P.; Puttasawat, B.; Yoosuk, B.; Chollacoop, N.; Faungnawakij, K. Waste shells of mollusk and egg as biodiesel production catalysts. Bioresour. Technol. 2010, 101, 3765-3767. [CrossRef]

112. Wei, Z.; Xu, C.; Li, B. Application of waste eggshell as low-cost solid catalyst for biodiesel production. Bioresour. Technol. 2009, 100, 2883-2885. [CrossRef]

113. Chen, G.; Shan, R.; Shi, J.; Yan, B. Ultrasonic-assisted production of biodiesel from transesterification of palm oil over ostrich eggshell-derived CaO catalysts. Bioresour. Technol. 2014, 171, 428-432. [CrossRef]

114. Tan, Y.H.; Abdullah, M.O.; Nolasco-Hipolito, C.; Zauzi, N.S.A. Application of RSM and Taguchi methods for optimizing the transesterification of waste cooking oil catalyzed by solid ostrich and chicken-eggshell derived CaO. Renew. Energy 2017, 114, 437-447. [CrossRef]

115. Gollakota, A.; Volli, V.; Shu, C.-M. Transesterification of waste cooking oil using pyrolysis residue supported eggshell catalyst. Sci. Total Environ. 2019, 661, 316-325. [CrossRef] [PubMed]

116. Umdu, E.S.; Tuncer, M.; Seker, E. Transesterification of Nannochloropsis oculata microalga's lipid to biodiesel on $\mathrm{Al}_{2} \mathrm{O}_{3}$ supported $\mathrm{CaO}$ and $\mathrm{MgO}$ catalysts. Bioresour. Technol. 2009, 100, 2828-2831. [CrossRef]

117. Witoon, T.; Bumrungsalee, S.; Vathavanichkul, P.; Palitsakun, S.; Saisriyoot, M.; Faungnawakij, K. Biodiesel production from transesterification of palm oil with methanol over $\mathrm{CaO}$ supported on bimodal meso-macroporous silica catalyst. Bioresour. Technol. 2014, 156, 329-334. [CrossRef]

118. Sawangkeaw, R.; Tejvirat, P.; Ngamcharassrivichai, C.; Ngamprasertsith, S. Supercritical Transesterification of Palm Oil and Hydrated Ethanol in a Fixed Bed Reactor with a $\mathrm{CaO} / \mathrm{Al}_{2} \mathrm{O}_{3}$ Catalyst. Energies 2012, 5, 1062-1080. [CrossRef]

119. Moradi, G.; Davoodbeygi, Y.; Mohadesi, M.; Hosseini, S. Kinetics of transesterification reaction using $\mathrm{CAO} / \mathrm{Al}_{2} \mathrm{O}_{3}$ catalyst synthesized by sol-gel method. Can. J. Chem. Eng. 2015, 93, 819-824. [CrossRef]

120. Kesserwan, F.; Ahmad, M.N.; Khalil, M.; El-Rassy, H. Hybrid CaO/Al2O3 aerogel as heterogeneous catalyst for biodiesel production. Chem. Eng. J. 2020, 385, 123834. [CrossRef]

121. Kachrimanidou, V.; Kopsahelis, N.; Alexandri, M.; Strati, A.; Gardeli, C.; Papanikolaou, S.; Komaitis, M.; Kookos, I.K.; Koutinas, A.A. Integrated sunflower-based biorefinery for the production of antioxidants, protein isolate and poly(3-hydroxybutyrate). Ind. Crop. Prod. 2015, 71, 106-113. [CrossRef]

122. Aghilinategh, M.; Barati, M.; Hamadanian, M. Supercritical methanol for one put biodiesel production from chlorella vulgaris microalgae in the presence of $\mathrm{CaO} / \mathrm{TiO}_{2}$ nano-photocatalyst and subcritical water. Biomass-Bioenergy 2019, 123, 34-40. [CrossRef]

123. Thitsartarn, W.; Kawi, S. An active and stable $\mathrm{CaO}-\mathrm{CeO}_{2}$ catalyst for transesterification of oil to biodiesel. Green Chem. 2011, 13, 3423-3430. [CrossRef]

124. Lee, H.; Juan, J.; Taufiq-Yap, Y. Preparation and application of binary acid-base $\mathrm{CaO}-\mathrm{La}_{2} \mathrm{O}_{3}$ catalyst for biodiesel production. Renew. Energy 2015, 74, 124-132. [CrossRef]

125. Liu, X.; He, H.; Wang, Y.; Zhu, S. Transesterification of soybean oil to biodiesel using SrO as a solid base catalyst. Catal. Commun. 2007, 8, 1107-1111. [CrossRef]

126. Singh, A.K.; Fernando, S.D. Reaction Kinetics of Soybean Oil Transesterification Using Heterogeneous Metal Oxide Catalysts. Chem. Eng. Technol. 2007, 30, 1716-1720. [CrossRef]

127. Viola, E.; Blasi, A.; Valerio, V.; Guidi, I.; Zimbardi, F.; Braccio, G.; Giordano, G. Biodiesel from fried vegetable oils via transesterification by heterogeneous catalysis. Catal. Today 2012, 179, 185-190. [CrossRef]

128. Koberg, M.; Gedanken, A. Direct Transesterification of Castor and Jatropha Seeds for FAME Production by Microwave and Ultrasound Radiation Using a SrO Catalyst. BioEnergy Res. 2012, 5, 958-968. [CrossRef]

129. Ali, S.D.; Javed, I.N.; Rana, U.A.; Nazar, M.F.; Ahmed, W.; Junaid, A.; Pasha, M.; Nazir, R.; Nazir, R. Novel SrO-CaO Mixed Metal Oxides Catalyst for Ultrasonic-Assisted Transesterification of Jatropha Oil into Biodiesel. Aust. J. Chem. 2017, 70, $258-264$. [CrossRef]

130. Mierczynski, P.; Ciesielski, R.; Kedziora, A.; Maniukiewicz, W.; Shtyka, O.; Kubicki, J.; Albinska, J.; Maniecki, T.P. Biodiesel Production on $\mathrm{MgO}, \mathrm{CaO}, \mathrm{SrO}$ and $\mathrm{BaO}$ Oxides Supported on $(\mathrm{SrO})\left(\mathrm{Al}_{2} \mathrm{O}_{3}\right)$ Mixed Oxide. Catal. Lett. 2015, 145, $1196-1205$. [CrossRef]

131. Anderson, J.A.; Beaton, A.; Galadima, A.; Wells, R.P.K. Role of Baria Dispersion in $\mathrm{BaO} / \mathrm{Al}_{2} \mathrm{O}_{3}$ Catalysts for Transesterification. Catal. Lett. 2009, 131, 213-218. [CrossRef]

132. Tonetto, G.M.; Marchetti, J.M. Transesterification of Soybean Oil Over $\mathrm{Me} / \mathrm{Al}_{2} \mathrm{O}_{3}(\mathrm{Me}=\mathrm{Na}, \mathrm{Ba}$, Ca, and K) Catalysts and Monolith $\mathrm{K} / \mathrm{Al}_{2} \mathrm{O}_{3}$-Cordierite. Top. Catal. 2010, 53, 755-762. [CrossRef] 
133. Mootabadi, H.; Abdullah, A.Z. Response Surface Methodology for Simulation of Ultrasonic-assisted Biodiesel Production Catalyzed by $\mathrm{SrO} / \mathrm{Al}_{2} \mathrm{O}_{3}$ Catalyst. Energy Sources Part A Recover. Util. Environ. Eff. 2015, 37, 1747-1755. [CrossRef]

134. Photaworn, S.; Tongurai, C.; Kungsanunt, S. Process development of two-step esterification plus catalyst solution recycling on waste vegetable oil possessing high free fatty acid. Chem. Eng. Process. Process. Intensif. 2017, 118, 1-8. [CrossRef]

135. Tangy, A.; Pulidindi, I.N.; Gedanken, A. $\mathrm{SiO}_{2}$ Beads Decorated with SrO Nanoparticles for Biodiesel Production from Waste Cooking Oil Using Microwave Irradiation. Energy Fuels 2016, 30, 3151-3160. [CrossRef]

136. Shahbazi, F.; Mahdavi, V.; Zolgharnein, J. Preparation and characterization of SrO/MgO nanocomposite as a novel and efficient base catalyst for biodiesel production from waste cooking oil: A statistical approach for optimization. J. Iran. Chem. Soc. 2020, 17, 333-349. [CrossRef]

137. Zhang, Y.; Niu, S.; Han, K.; Li, Y.; Lu, C. Synthesis of the $\mathrm{SrO}-\mathrm{CaO}-\mathrm{Al}_{2} \mathrm{O}_{3}$ trimetallic oxide catalyst for transesterification to produce biodiesel. Renew. Energy 2021, 168, 981-990. [CrossRef] 